(C) 2020 This manuscript version is made available under the CC-BY-NC-ND 4.0 license http://creativecommons.org/licenses/by-nc-nd/4.0/

\title{
Discovery of covalent prolyl oligopeptidase boronic ester inhibitors
}

Jessica Plescia, ${ }^{1}$ Caroline Dufresne, ${ }^{1}$ Naëla Janmamode ${ }^{1,+}$ Alexander. S. Wahba, ${ }^{1}$ Anthony K. Mittermaier, ${ }^{1}$ and Nicolas Moitessier ${ }^{1 *}$

${ }^{1}$ Department of Chemistry, McGill University, 801 Sherbrooke Street West, Montreal, QC, Canada H3A 0B8

ABSTRACT. Over the past decade, many drug discovery endeavors have been invested in targeting the serine proteases prolyl oligopeptidase (POP) for the treatment of Alzheimer's and Parkinson's disease and, more recently, epithelial cancers. Our research group has focused on the discovery of reversible covalent inhibitors, namely nitriles, to target the catalytic serine residue in this enzyme. While there have been many inhibitors discovered containing a nitrile to covalently bind to the catalytic serine, we have been investigating others, particularly boronic acids and boronic esters, the latter of which have been largely unexplored as covalent warheads. Herein we report a series of computationally-designed POP boronic ester inhibitors. These nanomolar-potent, easilyaccessible (1-2 step syntheses) compounds could facilitate future biochemical and biological studies of this enzyme's role in neurodegenerative diseases and cancer progression.

${ }^{*}$ Contact information for the author to whom correspondence should be addressed. E-mail: nicolas.moitessier@mcgill.ca

† Present Address: Naëla Janmamode, CQDM, 740 Rue Notre-Dame Ouest suite 1400, Montréal, QC H3C 3X6 


\section{Introduction}

Despite significant improvement in cancer therapies, survival rate remains low for several forms, such as lung cancer.[1] The tumor microenvironment (TME) - which includes malignant cells and the surrounding structures - is suggested to contribute to the metastasis and progression of tumors [2-4]. Many studies have been conducted to identify the structural targets implicated in tumors and the TME and in the development of drugs blocking the action of these targets [5-12]. Our focus is on prolyl oligopeptidase (POP), a serine protease of the $S 9$ protein family $[13,14]$. While initially linked to neurodegenerative diseases [15-17], POP has now been established as a viable candidate for cancer therapies and is suggested to be involved in angiogenesis through its proline-specific peptidase activity $[13,14,18]$. More specifically, POP inhibition has been shown to strongly inhibit the growth and proliferation of tumor cells in vivo [13, 14 , 18-21].

Thus far, the majority of POP dual inhibitors have heavily resembled its peptide substrates, with most structures consisting of modified dipeptides (or pseudopeptides) $[18,22-24]$. Research into drug-like dual inhibitors is a very promising strategy, as currently, there exist no inhibitors of POP on the market. S-17092, a potential POP selective inhibitor was stopped at phase I trials $[25,26]$.

Over the past few years, our group has reported three chemical series investigating POP covalent inhibition in vitro, both against recombinant protein and in cancer cell lines [2729], but the long and complex syntheses - including separation of diastereomers, enantiomeric resolution, and hazardous reaction conditions - prove to be inefficient for gram-scale synthesis and pharmaceutical development. Furthermore, each series 
focuses on the same 1,4-dicarbonyl molecular scaffold (1, 3, 4, 5, and $\mathbf{6}$ in Figure 1), and one series (4, MCMG01-2009 and analogues) was terminated due to metabolic instability and potential toxicity of the lead compound [30].

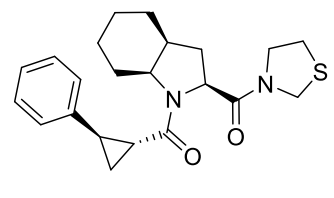

1, S-17092

$K_{\mathrm{i}}=1.5 \mathrm{nM}$
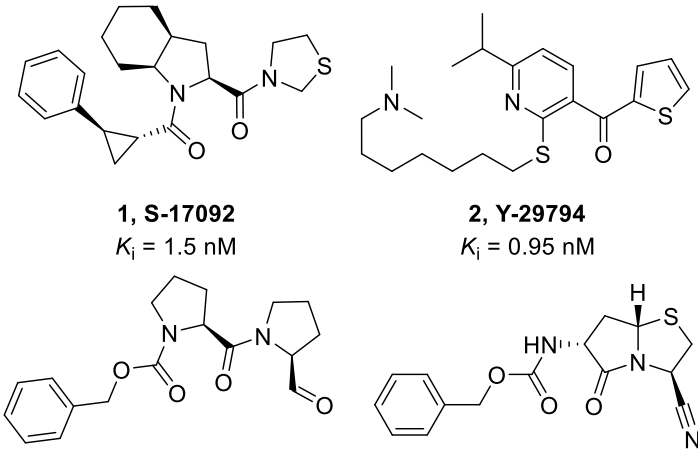

3, Z-Pro-Prolinal (ZPP)

$K_{\mathrm{i}}=1 \mathrm{nM}$

2, Y-29794

$K_{\mathrm{i}}=0.95 \mathrm{nM}$

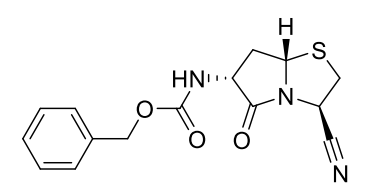

4, MCMG01-2009

$\mathrm{IC}_{50}=200 \mathrm{nM}$

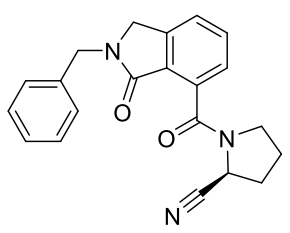

5a, MCMG02-2012

$K_{\mathrm{i}}=23 \mathrm{nM}$

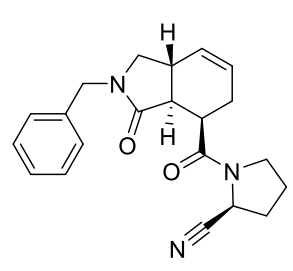

6, MCMG03-2016

$K_{\mathrm{i}}=1 \mathrm{nM}$

Figure 1. Previously-reported POP inhibitors.

These previous chemical series were discovered by docking-guided design of constrained peptidomimetics [27], virtual screening [28], and docking-guided optimization [29], using FORECASTER [31-33], a computational platform developed in our lab. The firstof-their-kind covalent inhibitors showed high activity in vitro, inhibitor 6 being one of the most potent compounds reported to date.

While reviewing the field of covalent enzyme inhibition, we concluded that, with the proper kinetics-structure relationship experiments, covalent inhibition could be a promising avenue in the discovery of anticancer therapeutics [34]. Our team has since developed 
the necessary kinetics experiments to study covalent inhibition in the context of POP inhibition [35-37].

In this work, we use our combined expertise in computational, medicinal, and biological chemistry to further explore the scope of POP inhibitors.

\section{RESULTS}

Docking-based investigations of the POP active site. It is now well established that docking-guided drug discovery endeavors are significantly more effective if knowledge of the target (e.g., key interacting residues) is available [38]. In order to obtain more insights into the optimal structural requirements for inhibition, we docked known active POP inhibitors (including those shown in Figure 1) and investigated the interactions between the inhibitors and the residues in the active sites, using the latest version of our docking program FITTED implemented in the FORECASTER platform [32, 33]. Our comprehensive review on POP inhibitors previously outlined the necessary interactions between inhibitors and the enzyme [18]. The results of this docking study supported our original findings that three residues participate in necessary interactions for high inhibitor activity: Phe173 for aromatic interactions and Trp595 and Arg643 for hydrogen bonding with potent POP inhibitors (Figure 2).

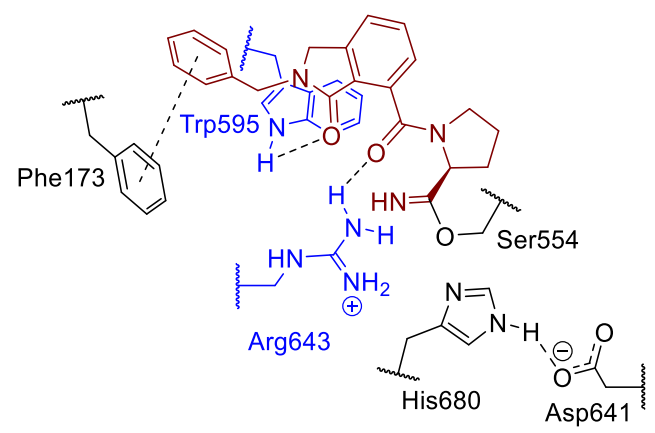


Figure 2. Compound 5a docked into the active site of POP. Hydrogen bonding interactions can be observed between the 1,4-carbonyl moiety and Trp595 and Arg643. An additional aromatic interaction can be observed between the benzyl group and Phe173.

Docking-guided optimizations. Once the necessary enzyme-inhibitor interactions were established, this information was converted into interaction sites to improve the docking predictions. Next, we carried out docking-guided optimizations. Of the known POP inhibitor structures, including those in Error! Reference source not found., compound $2[40,41]$ was particularly interesting. It is one of the only known active POP inhibitors that does not contain the aforementioned 1,4-dicarbonyl moiety that is presumed to offer hydrogen bonding to the arginine and tryptophan residues in the active site. Instead of a second carbonyl group, the scaffold contains a thioether as a hydrogen bond acceptor. In addition, it includes an aromatic core shared by one of our leads (5a, Figure 3 ). To the best of our knowledge, the mode of binding (competitive binding, allosteric, etc.) of inhibitor 2 remains unknown. However, computational studies revealed that binding in the catalytic site is possible [42]. Assuming that this compound binds to the active site, upon docking-guided optimizations of $\mathbf{2}$, compounds $7 \mathbf{a}-\mathbf{j}$ were designed, varying in heteroatoms on the scaffold and covalent warheads (Figure 3).

The docking pose of compound $\mathbf{2}$ was not optimal, so several modifications were made following information from our lead molecules $\mathbf{5 a}$ [28] and $\mathbf{5 b}$ [43] (Figure 3). The long chain of the thioether was removed, as it contained many rotatable bonds, subtracting from its viability as a drug candidate [44]. Unfortunately, the thioether analogue was not 
commercially available, and the synthesis was too complex for the purposes of this study. To address this issue, the thioether was replaced with a readily available methoxy group. Next, the distal amino-, pyridine, and alkyl moieties were combined into an $\mathrm{N}$-acetyl group, placed in the same position as the isopropyl group in $\mathbf{2}$. To determine the effect of the ether on inhibitor potency, an analog was synthesized containing a fluorine atom in place of the methoxy group. Interestingly, the docked pose of the fluorinated compound, like that of the -methoxy containing compound, orients the fluorine atom almost directly between Arg643 and Trp595, potentially interacting with both as a weak hydrogen bond acceptor (Figure 4). Series 7 was thus selected as the synthetic target.

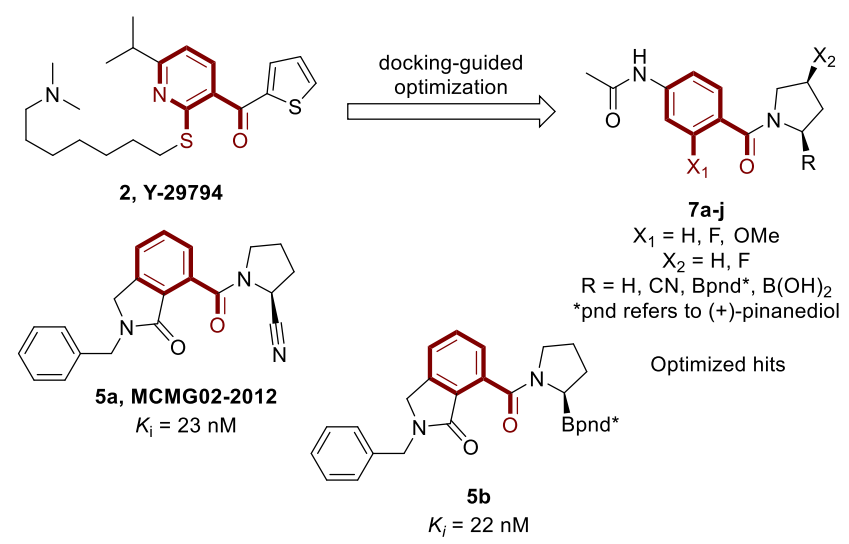

Figure 3. Docking guided optimization from compound $\mathbf{2}$, 5a [28] and $\mathbf{5 b}$ [45] to compounds $7 \mathrm{a}-\mathrm{j}$. 


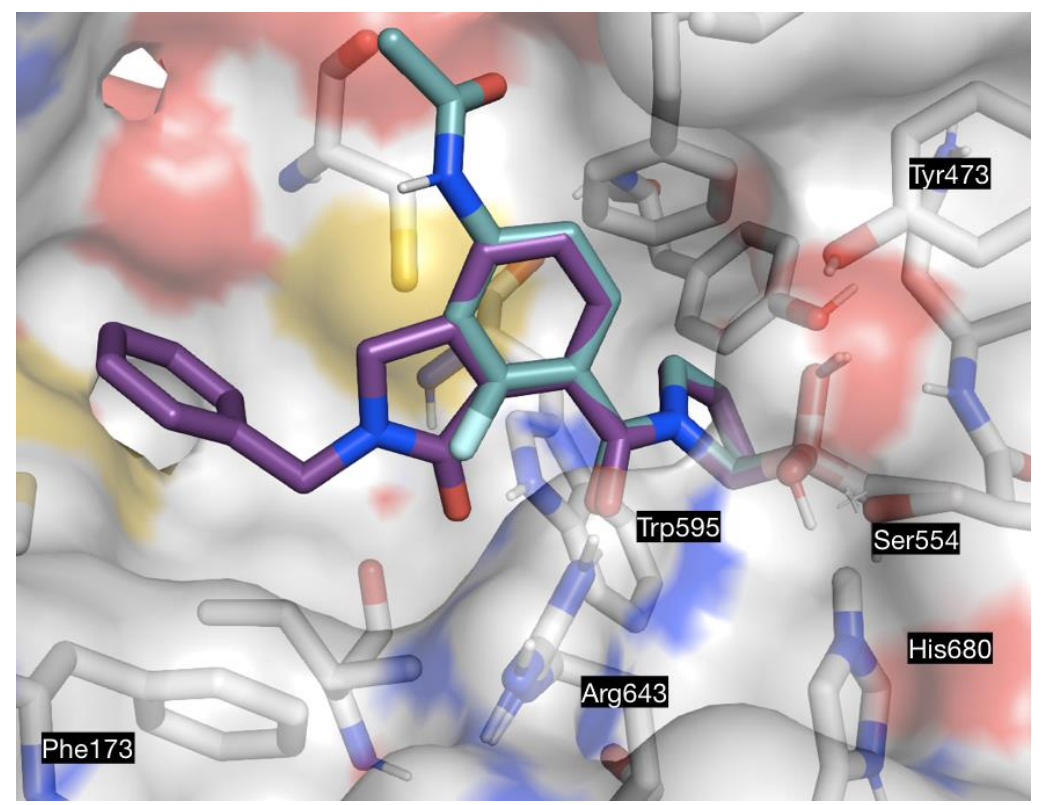

Figure 4. Compound $\mathbf{5 b}$ (purple; hydrolyzed to the boronic acid) and virtual hit $\mathbf{7 j}$ (teal) docked to the active site of POP.

Synthesis. Analogues both with and without the aromatic fluorine or methoxy group were synthesized to determine their effect on activity. The efficient synthesis was optimized to 1-2 steps, 3 including deprotection of the boronic ester to the corresponding boronic acid (Scheme 1). The first $\mathrm{N}$-acetylation step for the synthesis of the fluorine-containing series was adapted from a procedure by Veera Reddy et. al [46]. This reaction was carried out under sonication and proceeded smoothly, producing the benzoic acid derivative $\mathbf{1 0}$ in quantitative yields. The subsequent coupling step leading to $\mathbf{7 a - 7 k}$ gave varied yields. The amine salts were readily available proline analogues $[47,48]$. The potentially noncovalent inhibitor analogues $7 \mathbf{a}$ and $7 \mathbf{f}$ were included to determine the effect of a covalent group on the activity of the inhibitor. The boronic acid analogues were initially synthesized as boronic esters and required one further deprotection step to attain compounds $7 \mathbf{e} / \mathbf{7} \mathbf{j}$. 
Scheme 1. Synthesis of POP inhibitors ${ }^{a}$
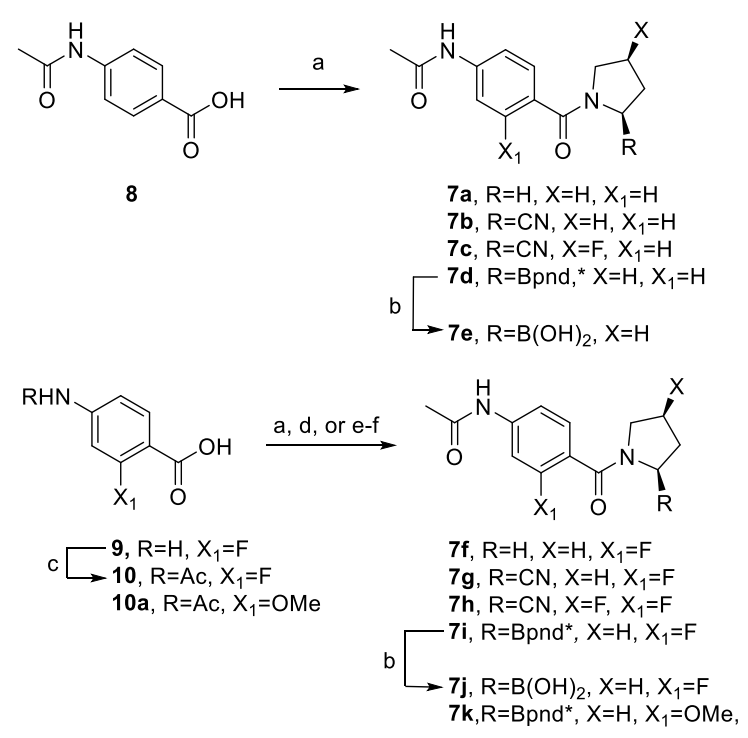

Reagents ${ }^{\mathrm{a}}:$ (a) $\mathrm{Et}_{3} \mathrm{~N}$, Piv-Cl, modified proline salt, $0^{\circ} \mathrm{C} \rightarrow \mathrm{RT}, 18 \mathrm{~h} ; 56 \%(7 \mathrm{a}), 25 \%$ (7b), 24\% (7c), 39\% (7f), 67\% (7g), 21\% (7h); (b) BCl 3 , DCM, $-78^{\circ} \mathrm{C}, 1 \mathrm{~h} ; 91 \%$ (7e), 71\% (7j); (c) $\mathrm{Ac}_{2} \mathrm{O}, \mathrm{H}_{2} \mathrm{O}$, sonication, (40 kHz), RT, quant.; (d) BOP, $\mathrm{Et}_{3} \mathrm{~N}$, modified proline salt, $18 \mathrm{~h}$; $82 \%$ (7d), 63\% (7i); (e) EDC $\bullet \mathrm{HCl}, \mathrm{HOSu}, \mathrm{DCM}, \mathrm{rt}, 18 \mathrm{~h}$; (f) $\mathrm{Et}_{3} \mathrm{~N}$, modified proline salt, $0^{\circ} \mathrm{C} \rightarrow \mathrm{RT}, 18 \mathrm{~h} ; 45 \%$ over two steps, See SI (7k); ${ }^{*}$ pnd refers to (+)-pinanediol.

Several analogues were next synthesized to explore the effect of fluorine and various combinations of functional groups on the activity of this new chemical series. The synthesis remained 1-2 steps as shown in Scheme 2. 
Scheme 2. Synthesis of second-generation analogues ${ }^{a}$
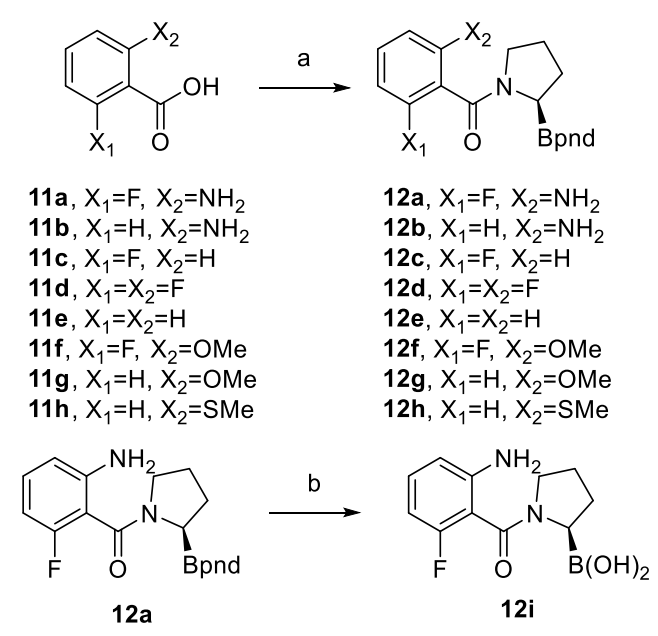

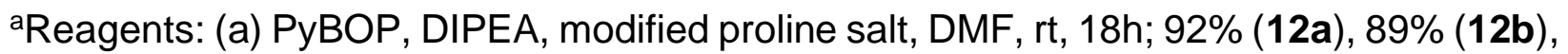
89\% (12c), 94\% (12d), 77\% (12e), 75\% (12f), 75\% (12g), 97\% (12h); b) BCl 3 , DCM, $78^{\circ} \mathrm{C} \rightarrow \mathrm{RT}, 18 \mathrm{~h}, 57 \%$; ${ }^{*}$ pnd refers to $(+)$-pinanediol.

\section{Discussion}

Inhibitory potency of the first series. Error! Reference source not found. summarizes the results from the in vitro assays of our inhibitor series on POP. As expected, the increase in activity from pyrrolidine $(\mathbf{7 a} / \mathbf{7 f})$ and cyanoproline $(\mathbf{7 b} / \mathbf{7 g})$ analogues in POP supports our argument that covalent inhibitors exhibit higher potencies than their non-covalent analogues. Interestingly, addition of a fluorine to the aromatic ring, while having little to no effect on the inhibitory activity of compounds containing the weakly-reactive nitrile group, shows a significant increase in activity of boronic ester compounds $\mathbf{7 d}$ and $\mathbf{7 i}$. Even without the understood requirement of aromatic interactions with Phe173, both compounds showed submicromolar activity, with fluorinated 7i showing nearly a 3-fold increase in potency from non-fluorinated $\mathbf{7 d}$. This contradicts our previous knowledge that the pharmacophore of POP inhibitors requires a phenyl ring to participate in aromatic interactions with Phe173 in the active site [18]. It appears as though fluorine, 
as predicted by our docking software, is oriented in such as a way as to compensate for the loss of these specific stabilizing interactions (Figure 4). To determine the significance of the fluorine, a boronic ester analogue replacing the fluorine for a methoxy group (7k) was also tested. Interestingly, this compound increased in potency by an order of magnitude, indicating that while fluorine must be participating in supplemental interactions or simply increasing the reactivity of the distal boronic ester, a true hydrogen bond acceptor renders the inhibitor much more potent.

Table 1. In vitro inhibitory potency against. POP.

\begin{tabular}{llllll}
\hline Entry & Compound \# & $\mathrm{X}$ & $\mathrm{X}_{1}$ & $\mathrm{R}$ & POP Ki $(\mu \mathrm{M})$ \\
\hline 1 & $\mathbf{7 a}$ & $\mathrm{H}$ & $\mathrm{H}$ & $\mathrm{H}$ & $>30$ \\
2 & $\mathbf{7 b}$ & $\mathrm{H}$ & $\mathrm{H}$ & $\mathrm{CN}$ & $2.2 \pm 0.7$ \\
3 & $\mathbf{7 c}$ & $\mathrm{F}$ & $\mathrm{H}$ & $\mathrm{CN}$ & $11.4 \pm 3.4$ \\
4 & $\mathbf{7 d}$ & $\mathrm{H}$ & $\mathrm{H}$ & $\mathrm{Bpnd}^{*}$ & $0.27 \pm 0.03$ \\
5 & $\mathbf{7 e}$ & $\mathrm{H}$ & $\mathrm{H}$ & $\mathrm{B}(\mathrm{OH})_{2}$ & $0.95 \pm 0.04$ \\
6 & $\mathbf{7 f}$ & $\mathrm{H}$ & $\mathrm{X}$ & $\mathrm{H}$ & $>30$ \\
7 & $\mathbf{7 g}$ & $\mathrm{H}$ & $\mathrm{X}$ & $\mathrm{CN}$ & $>15$ \\
8 & $\mathbf{7 h}$ & $\mathrm{F}$ & $\mathrm{X}$ & $\mathrm{CN}$ & $>15$ \\
9 & $\mathbf{7 i}$ & $\mathrm{H}$ & $\mathrm{X}$ & $\mathrm{Bpnd}^{*}$ & $0.08 \pm 0.015$ \\
10 & $\mathbf{7 j}$ & $\mathrm{H}$ & $\mathrm{X}$ & $\mathrm{B}(\mathrm{OH})_{2}$ & $0.21 \pm 0.03$ \\
11 & $\mathbf{7 k}$ & $\mathrm{H}$ & OMe & Bpnd & $0.006 \pm 0.0015$ \\
\hline${ }^{*}$ Bpnd refers to the (+)-pinanediol protecting group
\end{tabular}




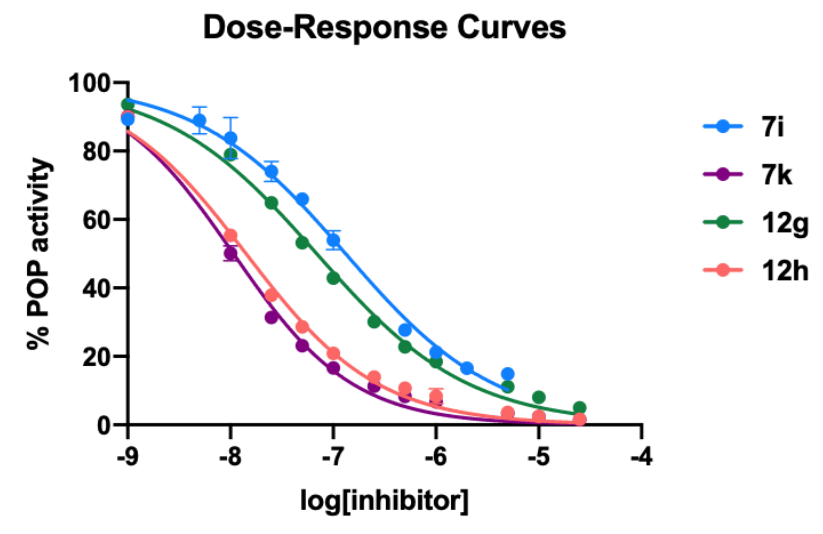

Figure 5. Dose-response curves for inhibitors $7 \mathbf{i}$ (blue), $\mathbf{7 k}$ (purple), $\mathbf{1 2 g}$ (green), and $\mathbf{1 2 h}$ (orange).

Hit optimization. The promising activity of compound $\mathbf{7} \mathbf{i}$ and $\mathbf{7 k}$ led to our further reoptimization of the scaffold. We hypothesized that if we moved the $N$-acetyl group to the ortho position, retaining the fluorine in the other ortho position, the activity would increase even further, as the hydrogen bond acceptor would be closer to the arginine and tryptophan residues. Upon docking, however, it appeared the $\mathrm{N}$-acetyl group was repelled from the active site. To decrease its size, the acetyl group was removed to leave the aniline group, giving compound 12a. Upon docking this new modification (Figure 6), the proposed binding mode was improved from the potent $7 \mathbf{7}$. However, although the fluorine was no longer interacting with two key residues, the aniline was predicted to hydrogen bond intramolecularly with the neighboring carbonyl. This interaction polarizes the carbonyl and may affect the reactivity of the boronic ester. Currently, the reactivity of the warhead is not considered by any docking program including routines for covalent docking [34]. Furthermore, the aniline would not hydrogen bond with the key tryptophan. 


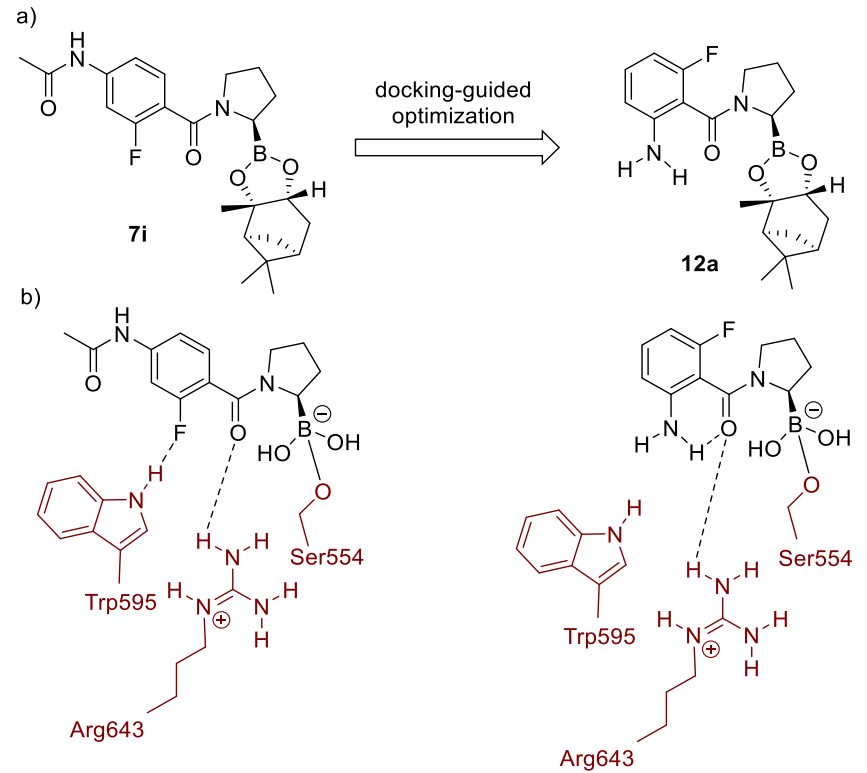

Figure 6. Docking-guided optimization of compound 7i.

In an alternative binding mode proposed by our docking program, the position of the fluorine in $\mathbf{1 2 a}$ is similar to that of $\mathbf{7} \mathbf{i}$, further supporting our hypothesis that the fluorine may compensate for the missing key interactions, and the aniline hydrogen-bonds to Tyr473, adding an additional stabilizing ligand-protein interaction.

In order to further probe the impact of the electronics on the inhibitory potency, a set of molecules with various electron donating and withdrawing groups was designed and synthesized (Scheme 2). Upon in vitro testing to POP, we obtained several interesting results. Our optimized hit 12a showed low micromolar potency against POP, yet it was still not nearly as active as our original hits $\mathbf{7 i}$ and $\mathbf{7 k}$. As discussed above, it is possible that after having removed the acetyl group and moved the resultant aniline to the ortho position, the aniline is hydrogen bonding intramolecularly to the carbonyl of the amide, thereby preventing the fluorine atom from assuming its predicted advantageous position in the active site. Removal of the aniline restored some of the activity (12c) while addition 
of a hydrogen bond acceptor (12f) led to further increase in potency by an order of magnitude. In contrast, removal of this fluorine (giving 12b) decreases the inhibitor potency six-fold, further suggesting that fluorine is contributing to the stabilization of the ligand in the active site or to the reactivity of the boronic ester acting as a warhead. These data indicated that (1) the aniline is potentially hindering activity of this new inhibitor and/or (2) fluorine on its own can lead to sub-micromolar inhibitory potency. This last observation may also suggest potentially quicker hydrolysis of the boronic ester in the buffer, as electronegative fluorine atoms are expected to increase the reactivity of boronic esters. This hydrolysis mechanism was investigated more closely (see below). Upon addition of a second ortho-fluorine (12d), an increase in potency of one order of magnitude is observed from the mono-fluorine analogue. Once more, two likely explanations exist for this activity: the di-fluoro system is inductively increasing the electrophilicity of the boronic ester (and its hydrolysis to the likely active species), and/or the two fluorine atoms are participating in supplementary stabilizing interactions that allow the inhibitor to interact with the active site more strongly than any of the other tested compounds. Another analogue featuring a methoxy group as a hydrogen bond acceptor (12g) displayed nanomolar activity in an even higher potency than 7i. Interestingly, replacement of the methoxy with a thioether (12h) increased potency further. This analogue more closely resembles active compound $\mathbf{2}$, the original scaffold from which this series was designed. It seems as though a thioether increases stability of the inhibitor in the active site more so than its methoxy counterpart. A control inhibitor with no ortho- substituents (12e) exhibited much lower potency, two orders of magnitude lower than the thioether or methoxy analogues. These results indicate that there does exist a substituent 
requirement for inhibitory potency, whether it be to stabilize the inhibitor in the active site, or to increase the reactivity of the boronic ester towards hydrolysis, or to form a stronger covalent bond in the binding site.

Table 2. In vitro on POP inhibition for second chemical series.

\begin{tabular}{lllll} 
& & & \\
& $\mathrm{d} \#$ & & & \\
\hline 1 & $\mathbf{1 2 a}$ & $\mathrm{F}$ & $\mathrm{NH}_{2}$ & $1.1 \pm 0.1$ \\
2 & $\mathbf{1 2 b}$ & $\mathrm{H}$ & $\mathrm{NH}_{2}$ & $6.3 \pm 0.5$ \\
3 & $\mathbf{1 2 c}$ & $\mathrm{F}$ & $\mathrm{H}$ & $1.0 \pm 0.1$ \\
4 & $\mathbf{1 2 d}$ & $\mathrm{F}$ & $\mathrm{F}$ & $0.355 \pm 0.054$ \\
7 & $\mathbf{1 2 e}$ & $\mathrm{H}$ & $\mathrm{H}$ & $0.767 \pm 0.1$ \\
8 & $\mathbf{1 2 f}$ & $\mathrm{F}$ & $\mathrm{OMe}$ & $0.049 \pm 0.008$ \\
9 & $\mathbf{1 2 g}$ & $\mathrm{H}$ & $\mathrm{OMe}$ & $0.044 \pm 0.004$ \\
10 & $\mathbf{1 2 h}$ & $\mathrm{H}$ & $\mathrm{SMe}$ & $0.009 \pm 0.001$ \\
11 & $\mathbf{1 2 i}$ & $\mathrm{F}$ & $\mathrm{NH} 2$ & $3.0 \pm 0.4$ \\
\hline
\end{tabular}

Mechanism of action. A close look at the collected data reveals that the activity of the boronic esters is most likely resulting from minor modifications of the scaffold. On one side, electron-withdrawing fluorine atoms are believed to increase the Lewis acidity of the boronic ester, hence its potency $\left(\mathrm{IC}_{50}(\mathbf{1 2 c})>\mathrm{IC}_{50}(\mathbf{1 2 d})\right)$. The introduction of true hydrogen 
bond acceptors $(\mathrm{OMe}, \mathrm{SMe})$ is expected to increase the potency $\left(\mathrm{IC}_{50}(\mathbf{1 2 e})>\mathrm{IC}_{50}(\mathbf{1 2 g})\right.$ $\left.>\mathrm{IC}_{50}(\mathbf{1 2 h})\right)$.

In order to determine the full effect of the boronic ester prodrug, the (+)-pinanediol group was removed under Lewis acidic conditions from two selected esters to give the corresponding boronic acids $\mathbf{7 e}$ and $\mathbf{7 j}$. Upon in vitro testing to POP, it was surprisingly found that the boronic acid analogues were slightly less active than their corresponding esters $\mathbf{7 d}$ and $\mathbf{7 i}$. This data appears inconsistent with the design strategy that relies upon the formation of a covalent bond between the boronic acid group and the catalytic serine. Based on these results, we hypothesized that the boronic pinanediol ester might be either (1) hydrolyzed in the buffer as we observed recently observed [43] or (2) a substrate of POP, hence the boronic acid, product of this hydrolysis, does not leave the binding site, inhibiting the enzymatic activity.

To distinguish between these two alternative boronic acid release pathways, we investigated the stability of the boronic ester in neutral aqueous solution and did not observe significant hydrolysis over a period of several hours. In fact, strongly acidic conditions are usually required to cleave alkyl boronic esters; $6 \mathrm{~N} \mathrm{HCl}$ was used by Lebarbier et al. [49], and boronic pinanediol esters were also found to be stable under acidic conditions used to remove a Boc group [50]. We were hence skeptical that hydrolysis would occur readily in the slightly basic buffer used in our assays. However, liquid chromatography mass spectrometry studies revealed that under the slightly basic conditions of the assay ( $\mathrm{pH} 8$ buffer), the ester was hydrolyzed very quickly even in the absence of enzyme. This data confirmed that the enzyme is not involved in the hydrolysis 
process. As a result, the boronic esters act as pro-drugs releasing the boronic esters in turn acting as POP inhibitors. Figure 7 details the hydrolysis of boronic ester $\mathbf{1 2 h}$.

Hydrolysis of $12 \mathrm{~h}$ in buffer

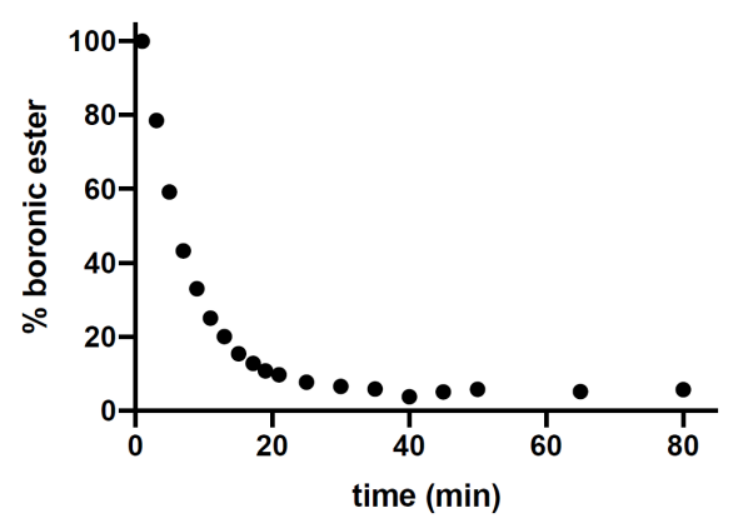

Figure 7. Hydrolysis of boronic ester $\mathbf{1 2 h}$ in POP assay buffer.

\section{Conclusion}

In summary, by introducing various combinations of amines/amides, hydrogen bond donors and acceptors, and fluorines, to a very simple molecular scaffold, we were able to achieve potent POP inhibition with compounds that move away from the pseudopeptide scaffold of previously-discovered inhibitors. Furthermore, our study has led to the synthesis of inhibitors that are available in just one or two steps, facilitating future kinetic or biological studies of this enzyme or cancer cell lines.

More unexpectedly, the boronic esters, initially seen as synthetic intermediates, exhibited strong inhibitory potency. We confirmed that the activity of these bulky boronic esters is the result of their buffer-mediated hydrolysis into the active boronic acids, the latter being less active (when tested directly); the boronic esters act as pro-drugs, while the boronic acids are the active species. This finding also facilitates future medicinal chemistry 
endeavors, as (1) boronic esters are much easier to synthesize and handle, and (2) many substituents are unstable to boronic ester cleavage conditions. The removal of this formerly necessary synthetic step allows for a broader spectrum of inhibitors to be studied. Based on these promising results of our boronic ester compounds, we are currently exploring more complex, non-peptidic boronic ester drugs.

\section{Experimental Section.}

In Vitro Assays. POP expression, purification, and testing were performed as previously described by our group [28]. The enzyme batch tested in this study exhibited a $K_{m}$ of $141.2 \mu \mathrm{M}$ and $\mathrm{k}_{\text {cat }}$ of $21.2 \mathrm{~s}^{-1}$. Dose-response curves are available in the Supporting Information.

\section{Chemistry}

General information. All commercially available reagents were used without further purification. All reactions, unless otherwise indicated, were carried out in flame-dried flasks under argon atmosphere with anhydrous solvents. FTIR spectra were recorded using a Perkin-Elmer Spectrum One FT-IR or Bruker ALPHA FTIR-ATR. ${ }^{1} \mathrm{H}$ and ${ }^{13} \mathrm{C}$ NMR spectra were recorded on Bruker 400 or $500 \mathrm{MHz}$ or Varian 400 or $500 \mathrm{MHz}$ spectrometers. Chemical shifts are reported in ppm using the residual of deuterated solvents as an internal standard. Thin layer chromatography visualization was performed by UV or by development using ninhydrin, para-anisaldehyde, vanillin, ceric ammonium molybdate, or $\mathrm{KMnO}_{4}$. Chromatography was performed on silica gel 60 (230-40 mesh) or using the Biotage One Isolera with ZIP cartridges. High resolution mass spectrometry was performed by ESI on a Bruker Maxis Impact API QqTOF or by ESI or APCI on a 
ThermoFisher Exactive Plus Orbitrap-API at McGill University. Prior to biological testing, reverse-phase HPLC was used to verify the purity of compounds on an Agilent 1100 series instrument, equipped with VWD-detector, using a C18 reverse column (Agilent, Eclipse -C18 $150 \mathrm{~mm} \AA \sim 4.6 \mathrm{~mm}, 5 \mu \mathrm{m}$ ) with UV detection at $254 \mathrm{~nm}$. All tested compounds were at least $95 \%$ pure. All compounds were stored at $-20^{\circ} \mathrm{C}$.

Liquid Chromatography Mass Spectroscopy study of boronic ester hydrolysis. This study was performed as previously published by our group [43].

4-acetamido-2-fluorobenzoic acid (10). 4-amino-2-fluorobenzoic acid benzoic acid (500 mg, $3.22 \mathrm{mmol}, 1 \mathrm{eq}$ ) was suspended in $\mathrm{H}_{2} \mathrm{O}(3.2 \mathrm{~mL}, 1 \mathrm{M})$ in a static-free roundbottom flask, and acetic anhydride $(0.65 \mathrm{~mL}, 658 \mathrm{mg}, 6.45 \mathrm{mmol}, 2 \mathrm{eq})$ was added. An empty balloon was inserted into the septum to trap $\mathrm{AcOH}$ vapors and prevent pressure build-up, and the mixture was sonicated for 5 minutes. The reaction was incomplete (TLC 90:10 EtOAc-MeOH, ninhydrin stain). Acetic anhydride (2 eq) was added again, and the mixture was sonicated for 5 minutes. This was repeated a third time (totaling 6 eq of $\mathrm{Ac}_{2} \mathrm{O}$, 15 minutes). The mixture was concentrated in vacuo to give a beige powder, which was taken to the next step without purification (635 mg, quant.) $\mathrm{R}_{f}=0.46$ (90:10 EtOAc$\mathrm{MeOH}$ ); $\mathrm{mp}=247-252^{\circ} \mathrm{C} ; \mathrm{IR}$ (neat) $\mathrm{cm}^{-1} 3329,3043,2924,2853,1687,1645,1603$, 1544, 866; ${ }^{1} \mathrm{H}$ NMR (500 MHz, DMSO-d $) \delta 12.93(\mathrm{~s}, 1 \mathrm{H}), 10.45(\mathrm{~s}, 1 \mathrm{H}), 7.82(\mathrm{t}, J=8.6$ $\mathrm{Hz}, 1 \mathrm{H}), 7.66(\mathrm{dd}, J=13.8,1.9 \mathrm{~Hz}, 1 \mathrm{H}), 7.34(\mathrm{dd}, J=8.6,1.9 \mathrm{~Hz}, 1 \mathrm{H}), 2.09(\mathrm{~s}, 3 \mathrm{H}) ;{ }^{13} \mathrm{C}$

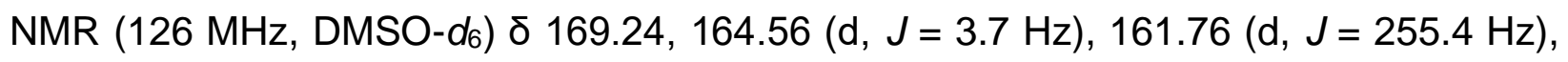
$144.76(\mathrm{~d}, J=11.9 \mathrm{~Hz}), 132.74(\mathrm{~d}, J=2.4 \mathrm{~Hz}), 114.05$ (d, $J=2.9 \mathrm{~Hz}), 112.84$ (d, $J=10.1$ $\mathrm{Hz}), 106.08(\mathrm{~d}, J=27.7 \mathrm{~Hz}), 24.19 ;{ }^{19} \mathrm{~F}$ NMR $\left(471 \mathrm{MHz}\right.$, Methanol- $\left.d_{4}\right) \delta-109.19(\mathrm{dd}, J=$ 
13.5, 8.4 Hz); HRMS (ESI+) $\mathrm{m} / \mathrm{z}$ calcd for $\left[\mathrm{C}_{9} \mathrm{H}_{8} \mathrm{O}_{3} \mathrm{NF}+\mathrm{Na}\right]^{+} 220.03804$, found 220.03742.

General Coupling Procedure A: The carboxylic acid starting material was suspended in $\mathrm{DCM}(0.1 \mathrm{M})$, and $\mathrm{Et}_{3} \mathrm{~N}$ (5 eq) was added. The resultant solution was cooled to $0^{\circ} \mathrm{C}$, and pivaloyl chloride $(1.1 \mathrm{eq})$ was added. After 30 minutes at $0^{\circ} \mathrm{C}$, the corresponding amine $(1.5 \mathrm{eq})$ was added, and the reaction stirred at room temperature overnight. The reaction was quenched with $\mathrm{H}_{2} \mathrm{O}$ (or $3 \mathrm{M} \mathrm{HCl}$ if a precipitate formed), and the product was extracted with DCM (or EtOAc for 7c and $\mathbf{7 h}$ ). The combined organic layers were washed with $1 \mathrm{M} \mathrm{HCl}$, saturated $\mathrm{NaHCO}_{3}$, and brine, dried over $\mathrm{Na}_{2} \mathrm{SO}_{4}$, filtered, and concentrated in vacuo. The crude product was purified by flash chromatography on silica gel to give the product as a solid. Trace impurities could be removed by trituration in hexanes or $\mathrm{Et}_{2} \mathrm{O}$ and subsequent vacuum filtration.

General Coupling Procedure B: The carboxylic acid starting material was dissolved in DMF (1 M), and BOP (1.2 eq) was added, followed by (1.2 eq) and $\mathrm{Et}_{3} \mathrm{~N}(3 \mathrm{eq})$. The reaction stirred at room temperature overnight. The reaction was quenched with $3 \mathrm{M} \mathrm{HCl}$, and the product was extracted with EtOAc. The combined organic layers were washed with $1 \mathrm{M} \mathrm{HCl}$, saturated $\mathrm{NaHCO}_{3}$, and brine, dried over $\mathrm{Na}_{2} \mathrm{SO}_{4}$, filtered, and concentrated in vacuo. The crude product was purified by flash chromatography on silica gel to give the product as an oil, which was precipitated in hexanes and vacuum filtered to give the product as a solid as a mixture of diastereomers.

General Coupling Procedure C: The carboxylic acid starting material was dissolved in DMF (1 M), and PyBOP (1.2 eq) was added, followed by (1 eq), and DIPEA (4 eq). The reaction stirred at room temperature overnight. The reaction was quenched with $\mathrm{H}_{2} \mathrm{O}$, and 
the product was extracted with EtOAc. The combined organic layers were washed with saturated $\mathrm{NaHCO}_{3}$ and brine, dried over $\mathrm{Na}_{2} \mathrm{SO}_{4}$, filtered, and concentrated in vacuo. The crude product was purified by flash chromatography on silica gel to give the product as a mixture of diastereomers.

General Coupling Procedure D: The carboxylic acid starting material was dissolved/suspended in DCM $(0.8 \mathrm{M})$, and the solution/mixture was cooled to $0^{\circ} \mathrm{C} . \mathrm{N}-$ hydroxysuccinimide (1 eq) was added, followed by EDC $\cdot \mathrm{HCl}(1 \mathrm{eq})$. The resultant solution was stirred at room temperature overnight. The activated esters were isolated via vacuum filtration. The activated ester was dissolved in DMF (0.2 M), and the solution was cooled to $0^{\circ} \mathrm{C}$. The $(1.5 \mathrm{eq})$ was added, followed by $\mathrm{Et}_{3} \mathrm{~N}(5 \mathrm{eq})$. The reaction stirred at room temperature until completion (1-18h). The reaction was quenched with $\mathrm{H}_{2} \mathrm{O}$, and the product was extracted with EtOAc. The combined organic layers were washed with saturated $\mathrm{NaHCO}_{3}$ and brine, dried over $\mathrm{Na}_{2} \mathrm{SO}_{4}$, filtered, and concentrated in vacuo. The crude product was purified by flash chromatography on silica gel to give the product as a mixture of diastereomers.

$\mathrm{N}$-(4-(pyrrolidine-1-carbonyl)phenyl)acetamide (7a). The product was synthesized following General Coupling Procedure A, using pyrrolidine as the corresponding amine. The crude product was purified by flash chromatography on a silica gel column (eluent 90:10 EtOAc-MeOH) to give a white solid $(56 \%) . \mathrm{R}_{f}=0.29(90: 10 \mathrm{EtOAc}-\mathrm{MeOH}) ; \mathrm{mp}=$ 201-205 ${ }^{\circ} \mathrm{C}$; IR (neat) $\mathrm{cm}^{-1} 3244,3039,2975,1697,1603,759 ;{ }^{1} \mathrm{H}$ NMR $(500 \mathrm{MHz}$, Chloroform-d) $\delta 9.16(\mathrm{~s}, 1 \mathrm{H}), 7.50(\mathrm{~d}, J=8.7 \mathrm{~Hz}, 2 \mathrm{H}), 7.36$ (d, J = 8.7 Hz, 2H), 3.60 (t, J $=7.0 \mathrm{~Hz}, 2 \mathrm{H}), 3.41(\mathrm{t}, J=6.7 \mathrm{~Hz}, 2 \mathrm{H}), 2.09(\mathrm{~s}, 4 \mathrm{H}), 1.93(\mathrm{p}, J=6.9 \mathrm{~Hz}, 2 \mathrm{H}), 1.85(\mathrm{p}, J=$ $6.7 \mathrm{~Hz}, 2 \mathrm{H}) ;{ }^{13} \mathrm{C} \mathrm{NMR}\left(126 \mathrm{MHz}, \mathrm{CDCl}_{3}\right) \delta 169.75,169.52,140.40,131.75,127.97$ (2C), 
119.35 (2C), 49.88, 46.48, 26.47, 24.49, 24.43; HRMS (ESI+) $\mathrm{m} / z$ calcd for $\left[\mathrm{C}_{13} \mathrm{H}_{16} \mathrm{O}_{2} \mathrm{~N}_{2}\right.$ $+\mathrm{H}]^{+}$233.1285, found 233.1294.

(S)-N-(4-(2-cyanopyrrolidine-1-carbonyl)phenyl)acetamide (7b). The product was synthesized following General Coupling Procedure A, using (S)-pyrrolidine-2-carbonitrile pTsOH salt (prepared as described in the literature[48]) as the corresponding amine. The crude product was purified by flash chromatography on a silica gel column (eluent 90:10 EtOAc-MeOH) to give a white solid (25\%). $\mathrm{R}_{f}=0.60$ (90:10 EtOAc-MeOH); $\mathrm{mp}=171-$ $174^{\circ} \mathrm{C}$; IR (neat) $\mathrm{cm}^{-1} 3325,3110,2986,2244,1693,1606,1596,1526,853 . ;{ }^{1} \mathrm{H}$ NMR (500 MHz, Chloroform-d) $\delta 8.86(\mathrm{~s}, 1 \mathrm{H}), 7.55(\mathrm{~d}, J=8.3 \mathrm{~Hz}, 2 \mathrm{H}), 7.44(\mathrm{~d}, J=8.4 \mathrm{~Hz}, 2 \mathrm{H})$, $4.81(\mathrm{~m}, 1 \mathrm{H}), 3.68-3.57(\mathrm{~m}, 1 \mathrm{H}), 3.57-3.44(\mathrm{~m}, 1 \mathrm{H}), 2.36-2.23(\mathrm{~m}, 2 \mathrm{H}), 2.18-2.14$ $(\mathrm{m}, 1 \mathrm{H}), 2.12(\mathrm{~s}, 3 \mathrm{H}), 2.11-2.07(\mathrm{~m}, 1 \mathrm{H}), 2.05-1.93(\mathrm{~m}, 1 \mathrm{H}) ;{ }^{13} \mathrm{C}$ NMR $(126 \mathrm{MHz}$, $\left.\mathrm{CDCl}_{3}\right) \delta 24.49,25.67,30.27,47.10,49.77,118.77,119.37$ (2C), 128.50 (2C), 129.60, 141.13, 169.58, 169.80; HRMS (ESI+) $m / z$ calcd for $\left[\mathrm{C}_{14} \mathrm{H}_{15} \mathrm{O}_{2} \mathrm{~N}_{3}+\mathrm{H}\right]^{+} 258.1237$, found 258.1241.

$N$-(4-((2S,4S)-2-cyano-4-fluoropyrrolidine-1-carbonyl)phenyl)acetamide (7c). The product was synthesized following General Coupling Procedure A, using 2-(S)-cyano-4(S)-fluoropyrrolidine hydrochloride (prepared as described in the literature[48]) as the corresponding amine. The crude product was purified by flash chromatography on a silica gel column (eluent 90:10 EtOAc- $\mathrm{MeOH}+1.5 \% \mathrm{Et}_{3} \mathrm{~N}$ ) to give a yellow solid. The solid was triturated in diethyl ether and vacuum filtered to give the final product as a yellow solid (10\%). $\mathrm{R}_{f}=0.45(90: 10 \mathrm{EtOAc}-\mathrm{MeOH}) ; \mathrm{mp}=111-114^{\circ} \mathrm{C} ; \mathrm{IR}$ (neat) $\mathrm{cm}^{-1} 3308,3189$ 2987, 1665, 1626, 1607, 1542, 839; ${ }^{1} \mathrm{H}$ NMR $\left(500 \mathrm{MHz}\right.$, Methanol- $\left.d_{4}\right) \delta 7.69(\mathrm{~d}, J=8.5$ $\mathrm{Hz}, 2 \mathrm{H}), 7.56(\mathrm{~d}, J=8.6 \mathrm{~Hz}, 2 \mathrm{H}), 5.38(\mathrm{~d}, J=51.7 \mathrm{~Hz}, 1 \mathrm{H}), 5.19-4.96(\mathrm{~m}, 1 \mathrm{H}), 4.10-$ 
$3.61(\mathrm{~m}, 2 \mathrm{H}), 2.76-2.38(\mathrm{~m}, 2 \mathrm{H}), 2.15(\mathrm{~s}, 3 \mathrm{H}) ;{ }^{13} \mathrm{C}$ NMR $\left(126 \mathrm{MHz}\right.$, Methanol- $\left.d_{4}\right) \delta 171.86$ (2C), 142.65, 131.01, 129.32 (2C), 120.43 (2C), 119.30, 93.83 (d, $J=172.0 \mathrm{~Hz}$ ), 56.66 $(\mathrm{d}, J=23.1 \mathrm{~Hz}), 46.81,37.18(\mathrm{~d}, J=21.7 \mathrm{~Hz}), 23.97 ;{ }^{19} \mathrm{~F}$ NMR $(471 \mathrm{MHz}, \mathrm{MeOD}) \delta-$ 76.94; $\mathrm{HRMS}(\mathrm{ESI}+) \mathrm{m} / z$ calcd for $\left[\mathrm{C}_{14} \mathrm{H}_{14} \mathrm{FO}_{2} \mathrm{~N}_{3}+\mathrm{Na}\right]^{+} 298.0962$, found 298.0976.

\section{$N-(4-(2-((3 a S, 4 S, 6 S, 7 a R)-3 a, 5,5-t r i m e t h y l h e x a h y d r o-4,6-$}

methanobenzo[ $d][1,3,2]$ dioxaborol-2-yl)pyrrolidine-1-carbonyl) phenyl)acetamide

(7d). The product was synthesized following General Coupling Procedure B. The crude residue was purified by flash chromatography on a silica gel column (eluent $80 \rightarrow 100 \%$ EtOAc in hexanes, then $10 \% \mathrm{MeOH}$ in EtOAc) to give a white solid as a mixture of diastereomers (75\%). $\mathrm{R}_{f}=0.26(100 \% \mathrm{EtOAc}) ; \mathrm{mp}=159-162^{\circ} \mathrm{C}$; IR (in $\left.\mathrm{CDCl}_{3}\right) \mathrm{cm}^{-1} 3266$ 3190, 2921, 1699, 1679, 1602, 1514, 1457, 1385, 1372, 1124; Proton coupling constants are reported for both diastereomers. ${ }^{1} \mathrm{H}$ NMR $(500 \mathrm{MHz}$, Chloroform- $d) \delta 8.94(\mathrm{~s}, 1 \mathrm{H})$, $8.80(\mathrm{~s}, 1 \mathrm{H}), 7.53$ (dd, $J=8.5,2.7 \mathrm{~Hz}, 4 \mathrm{H}), 7.45(\mathrm{~d}, J=8.4 \mathrm{~Hz}, 2 \mathrm{H}), 7.41(\mathrm{~d}, J=8.4 \mathrm{~Hz}$, 2H), 4.30 (ddd, $J=20.0,8.8,2.2 \mathrm{~Hz}, 2 \mathrm{H}$ ), 3.60 (tt, $J=9.1,4.0 \mathrm{~Hz}, 2 \mathrm{H}$ ), 3.41 (p, $J=8.6$ Hz, 2H), 3.04 (ddd, $J=15.4,11.2,6.8 \mathrm{~Hz}, 2 \mathrm{H}$ ), 2.36 (ddt, $J=14.6,8.9,3.0 \mathrm{~Hz}, 2 \mathrm{H}$ ), 2.19 (s, 3H), $2.18(\mathrm{~s}, 3 \mathrm{H}), 2.17-2.08(\mathrm{~m}, 4 \mathrm{H}), 2.08-2.00(\mathrm{~m}, 4 \mathrm{H}), 1.99-1.92(\mathrm{~m}, 2 \mathrm{H}), 1.92$ $-1.87(\mathrm{~m}, 3 \mathrm{H}), 1.87-1.83(\mathrm{~m}, 1 \mathrm{H}), 1.76-1.66(\mathrm{~m}, 2 \mathrm{H}), 1.52(\mathrm{dd}, J=10.5,7.6 \mathrm{~Hz}, 2 \mathrm{H})$, $1.49(\mathrm{~s}, 3 \mathrm{H}), 1.48(\mathrm{~s}, 3 \mathrm{H}), 1.29(\mathrm{~s}, 6 \mathrm{H}), 0.88(\mathrm{~s}, 6 \mathrm{H}) ;$ Carbon peaks are reported for both diastereomers. ${ }^{13} \mathrm{C}$ NMR (126 MHz, $\mathrm{CDCl}_{3}$ ) $\delta 24.36$ (2C), 24.60, 24.66, 25.77, 26.08, $26.67,26.77,27.51,27.54,28.80,28.87,29.53,29.66,36.94(2 \mathrm{C}), 38.31,38.33,40.25$, 40.29, 48.56, 48.62, 51.93 (2C), 52.58, 52.61, 76.72, 76.82, 83.85, 83.98, 119.66 (2C), $119.69(2 \mathrm{C}), 124.32,124.53,130.00$ (2C), $130.22(2 \mathrm{C}), 141.89,141.98,169.37,169.42$ 
170.45, 170.64; ${ }^{11} \mathrm{~B}$ NMR (161 MHz, $\left.\mathrm{CDCl}_{3}\right) \delta$ 19.26; HRMS (ESI+) $\mathrm{m} / \mathrm{z}$ calcd for $\left[\mathrm{C}_{23} \mathrm{H}_{31} \mathrm{O}_{4} \mathrm{~N}_{2} \mathrm{~B}+\mathrm{H}\right]^{+} 411.2450$, found 411.2450 .

$\mathrm{N}$-(3-fluoro-4-(pyrrolidine-1-carbonyl)phenyl)acetamide (7f). The product was synthesized following General Coupling Procedure A, using pyrrolidine as the corresponding amine. The crude product was purified by flash chromatography on a silica gel column (eluent 90:10 EtOAc-MeOH) to give a yellow solid (39\%). $\mathrm{R}_{f}=0.5(90: 10$ EtOAc-MeOH); $\mathrm{mp}=187-190^{\circ} \mathrm{C}$; IR (neat) $\mathrm{cm}^{-1} 3252,3095,2965,1597,828,867 ;{ }^{1} \mathrm{H}$ NMR (500 MHz, Chloroform- $d$ ) $\delta 9.65(\mathrm{~s}, 1 \mathrm{H}), 7.54$ (dd, $J=12.2,1.9 \mathrm{~Hz}, 1 \mathrm{H}), 7.18-7.13$ (m, 1H), 7.09 (dd, $J=8.4,1.9 \mathrm{~Hz}, 1 \mathrm{H}), 3.58(\mathrm{t}, J=7.0 \mathrm{~Hz}, 2 \mathrm{H}), 3.29(\mathrm{t}, J=6.7 \mathrm{~Hz}, 2 \mathrm{H})$, $2.05(\mathrm{~s}, 3 \mathrm{H}), 1.93(\mathrm{p}, J=6.4 \mathrm{~Hz}, 2 \mathrm{H}), 1.86(p, J=6.1 \mathrm{~Hz}, 2 \mathrm{H}) ;{ }^{13} \mathrm{C}$ NMR $(126 \mathrm{MHz}$, Chloroform- $d$ ) $\delta$ 169.79, 165.59, 158.41 (d, $J=246.2 \mathrm{~Hz}), 141.96(\mathrm{~d}, J=11.1 \mathrm{~Hz}), 128.57$ (d, $J=5.1 \mathrm{~Hz}), 119.65(\mathrm{~d}, J=17.8 \mathrm{~Hz}), 115.28(\mathrm{~d}, J=2.8 \mathrm{~Hz}), 107.19(\mathrm{~d}, J=27.0 \mathrm{~Hz})$, $48.13(\mathrm{~d}, J=4.1 \mathrm{~Hz}), 46.12,25.85,24.48,24.23 ;{ }^{19} \mathrm{~F} \mathrm{NMR}(471 \mathrm{MHz}$, Chloroform- $d$ ) $\delta$ $112.73(\mathrm{dd}, J=12.0,7.5 \mathrm{~Hz}) ; \mathrm{HRMS}(\mathrm{ESI}+) \mathrm{m} / z$ calcd for $\left[\mathrm{C}_{13} \mathrm{H}_{15} \mathrm{FO}_{2} \mathrm{~N}_{2}+\mathrm{H}\right]^{+} z 251.1190$, found 251.1189 .

(S)-N-(4-(2-cyanopyrrolidine-1-carbonyl)-3-fluorophenyl)acetamide $\quad$ (7g). The product was synthesized following General Coupling Procedure A, using (S)-pyrrolidine2-carbonitrile $\mathrm{pTsOH}$ salt (prepared as described in the literature[48]) as the corresponding amine. The crude product was purified by flash chromatography on a silica gel column (eluent 90:10 EtOAc-MeOH) to give a yellow solid $(74 \%) . R_{f}=0.53(90: 10$ EtOAc-MeOH); $\mathrm{mp}=157-161^{\circ} \mathrm{C}$; IR (neat) $\mathrm{cm}^{-1} 3267,3106,2984,2237,1693,1615$, 1597, 881, 825.; Proton coupling constants are reported for the major rotamer; a full ${ }^{1} \mathrm{H}$ spectrum with all rotamers integrated and associated HSQC spectrum are provided as 
Supporting Information. ${ }^{1} \mathrm{H}$ NMR $(500 \mathrm{MHz}$, Chloroform-d) $\delta 9.02(\mathrm{~s}, 1 \mathrm{H}), 7.61(\mathrm{dd}, \mathrm{J}=$ 12.3, $1.9 \mathrm{~Hz}, 1 \mathrm{H}), 7.25(\mathrm{t}, J=8.0 \mathrm{~Hz}, 1 \mathrm{H}), 7.11(\mathrm{dd}, J=8.4,1.9 \mathrm{~Hz}, 1 \mathrm{H}), 4.81(\mathrm{dd}, J=$ 7.1, $5.1 \mathrm{~Hz}, 1 \mathrm{H}$ ), 3.51 (ddd, $J=10.5,7.4,5.2 \mathrm{~Hz}, 1 \mathrm{H}$ ), 3.41 (dt, $J=10.4,7.1 \mathrm{~Hz}, 1 \mathrm{H}), 2.39$ $-2.30(\mathrm{~m}, 2 \mathrm{H}), 2.19-2.13(\mathrm{~m}, 1 \mathrm{H}), 2.11(\mathrm{~s}, 3 \mathrm{H}), 2.08-1.96(\mathrm{~m}, 1 \mathrm{H}) ;{ }^{13} \mathrm{C}$ NMR $(126$ $\mathrm{MHz}$, Chloroform-d) $\delta$ 169.71, 166.01, 158.78 (d, $J=247.8 \mathrm{~Hz}), 142.58(\mathrm{~d}, J=11.3 \mathrm{~Hz})$, $129.26(\mathrm{~d}, J=4.5 \mathrm{~Hz}), 118.36,117.97(\mathrm{~d}, J=17.0 \mathrm{~Hz}), 115.38,107.27(\mathrm{~d}, J=27.0 \mathrm{~Hz})$, $47.97(\mathrm{~d}, J=5.0 \mathrm{~Hz}), 46.73,30.43,25.12,24.45$; Fluorine coupling constants are reported for the major rotamer; a full ${ }^{19} \mathrm{~F}$ spectrum with all rotamers integrated is provided ${ }^{19} \mathrm{~F}$ NMR (471 MHz, Chloroform- $d$ ) $\delta-111.90(\mathrm{dd}, J=12.5,7.6 \mathrm{~Hz})$; HRMS (ESI+) $\mathrm{m} / \mathrm{z}$ calcd for $\left[\mathrm{C}_{14} \mathrm{H}_{14} \mathrm{FO}_{2} \mathrm{~N}_{3}+\mathrm{H}\right]^{+}$276.1143, found 276.1140.

\section{$N$-(4-((2S,4S)-2-cyano-4-fluoropyrrolidine-1-carbonyl)-3-fluorophenyl)acetamide}

(7h). The product was synthesized following General Coupling Procedure A, using 2-(S)cyano-4-(S)-fluoropyrrolidine hydrochloride (prepared as described in the literature[48]) as the corresponding amine. The crude product was purified by flash chromatography on a silica gel column (eluent 90:10 EtOAc-MeOH) to give a yellow solid. The solid was triturated in diethyl ether and vacuum filtered to give the final product as a pink solid $(10 \%) . R_{f}=0.53\left(90: 10\right.$ EtOAc-MeOH); $\mathrm{mp}=112-116^{\circ} \mathrm{C} ; \mathrm{IR}$ (neat) $\mathrm{cm}^{-1} 3309,3124$ $2985,2244,1664,1624,1604,1543,911,800 ; 1 H), 4.16-3.57(m, 2 H), 2.79-2.45(m$, 2H), $2.15(\mathrm{~s}, 3 \mathrm{H}) ;{ }^{13} \mathrm{C} \mathrm{NMR}\left(126 \mathrm{MHz}\right.$, Methanol- $\left.d_{4}\right) \delta 171.95,167.50,159.92(\mathrm{~d}, J=$ $246.1 \mathrm{~Hz}), 144.20$ (d, $J=11.4 \mathrm{~Hz}), 130.33(\mathrm{~d}, J=4.5 \mathrm{~Hz}), 119.18$ (d, $J=17.3 \mathrm{~Hz}), 118.94$, $116.47(\mathrm{~d}, J=2.9 \mathrm{~Hz}), 107.87(\mathrm{~d}, J=26.9 \mathrm{~Hz}), 93.60(\mathrm{~d}, J=177.9 \mathrm{~Hz}), 55.43(\mathrm{~d}, J=4.6$ $\mathrm{Hz}), 55.24(\mathrm{~d}, J=4.5 \mathrm{~Hz}), 37.38(\mathrm{~d}, J=20.9 \mathrm{~Hz}), 24.00 ;{ }^{19} \mathrm{~F} \mathrm{NMR}(471 \mathrm{MHz}$, Methanol- 
$\left.d_{4}\right) \delta-114.60--114.88(\mathrm{~m})$; HRMS $(\mathrm{ESI}+) \mathrm{m} / z$ calcd for $\left[\mathrm{C}_{14} \mathrm{H}_{13} \mathrm{~F}_{2} \mathrm{O}_{2} \mathrm{~N}_{3}+\mathrm{Na}\right]^{+} 316.0868$ found 316.0868 .

\section{N-(3-fluoro-4-(2-((3aS,4S,6S,7aR)-3a,5,5-trimethylhexahydro-4,6-}

\section{methanobenzo[d][1,3,2]dioxaborol-2-yl)pyrrolidine-1-carbonyl)phenyl) acetamide}

(7i). The product was synthesized following General Coupling Procedure B, using as the corresponding amine. The crude residue was purified by flash chromatography on a silica gel column (eluent $80 \rightarrow 100 \%$ EtOAc in hexanes) to give a white solid as a mixture of diastereomers (63\%). $\mathrm{R}_{f}=0.36(100 \% \mathrm{EtOAc}) ; \mathrm{mp}=142-146^{\circ} \mathrm{C}$; IR (in $\left.\mathrm{CDCl}_{3}\right) \mathrm{cm}^{-1} 3270$, $3111,2968,2921,1699,1683,1606,1455,1389,1376,1249 ;$ Proton coupling constants are reported for the major rotamer and as one diastereomer; a full ${ }^{1} \mathrm{H}$ spectrum with all rotamers integrated is provided as Supporting Information. ${ }^{1} \mathrm{H}$ NMR $(400 \mathrm{MHz}$, Chloroform- $d$ ) $\delta 8.78(\mathrm{~s}, 1 \mathrm{H}), 7.50(\mathrm{dd}, J=11.9,2.0 \mathrm{~Hz}, 1 \mathrm{H}), 7.33-7.21(\mathrm{~m}, 1 \mathrm{H}), 7.07$ (dt, $J=8.4,1.8 \mathrm{~Hz}, 1 \mathrm{H}), 4.32(\mathrm{td}, J=8.6,8.1,1.9 \mathrm{~Hz}, 1 \mathrm{H}), 3.48-3.36(\mathrm{~m}, 1 \mathrm{H}), 3.40-$ $3.23(\mathrm{~m}, 2 \mathrm{H}), 2.39-2.26(\mathrm{~m}, 1 \mathrm{H}), 2.23-2.12(\mathrm{~m}, 1 \mathrm{H}), 2.12(\mathrm{~s}, 3 \mathrm{H}), 2.12-1.98(\mathrm{~m}, 3 \mathrm{H})$, $1.99-1.90(\mathrm{~m}, 1 \mathrm{H}), 1.93-1.81(\mathrm{~m}, 3 \mathrm{H}), 1.50-1.33(\mathrm{~m}, 4 \mathrm{H}), 1.30-1.25(\mathrm{~m}, 3 \mathrm{H}), 0.87$ $-0.72(\mathrm{~m}, 3 \mathrm{H})$; Carbon peaks are reported for the major rotamer (of both diastereomers); a full ${ }^{13} \mathrm{C}$ spectrum plus the HSQC are provided as Supporting Information. ${ }^{13} \mathrm{C}$ NMR $(126$ $\mathrm{MHz}$, Chloroform-d) $\delta 169.43,169.42,165.66,165.39,158.99$ (d, $J=248.5 \mathrm{~Hz}), 159.07$ (d, $J=248.9 \mathrm{~Hz}), 142.17(\mathrm{~d}, J=11.3 \mathrm{~Hz}), 141.97(\mathrm{~d}, J=11.5 \mathrm{~Hz}), 129.81(\mathrm{~d}, J=4.5 \mathrm{~Hz})$, $129.53(\mathrm{~d}, J=4.6 \mathrm{~Hz}), 118.19(\mathrm{~d}, J=17.0 \mathrm{~Hz}), 117.62(\mathrm{~d}, J=16.7 \mathrm{~Hz}), 115.36,115.34$, $107.57(\mathrm{~d}, J=6.6 \mathrm{~Hz}), 107.36(\mathrm{~d}, J=6.8 \mathrm{~Hz}), 85.63,85.51,77.89,77.66,51.75,51.70$, $48.01(\mathrm{~d}, J=4.5 \mathrm{~Hz}), 47.89$ (d, $J=5.0 \mathrm{~Hz}), 46.51,46.07,39.83,39.77,38.36$ (2C), 36.02, $35.96,28.97,28.85,27.36,27.31,27.29$ (2C), 27.20, 27.02, 26.53, 26.42, 24.53, 24.51, 
$24.23(2 \mathrm{C}) ;{ }^{19} \mathrm{~F}$ NMR taken with ${ }^{1} \mathrm{H}$ decoupling. Peaks listed for major rotamers; full spectrum provided with rotamers integrated as Supporting Information. ${ }^{19} \mathrm{~F}$ NMR $(471$ $\left.\mathrm{MHz}, \mathrm{CDCl}_{3}\right)-111.34,-110.81 ;$ Boron peak is reported for the major rotamer; full spectrum provided with rotamers integrated as Supporting Information. ${ }^{11} \mathrm{~B} \mathrm{NMR}\left(161 \mathrm{MHz}, \mathrm{CDCl}_{3}\right)$

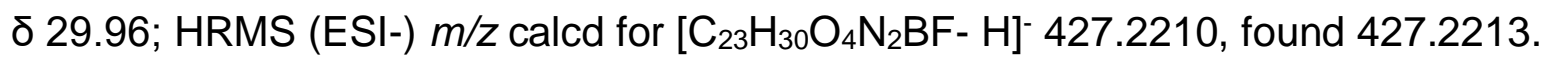

N-(3-methoxy-4-(2-((3aS,4S,6S,7aR)-3a,5,5-trimethylhexahydro-4,6methanobenzo[d][1,3,2]dioxaborol-2-yl)pyrrolidine-1-carbonyl)phenyl) acetamide (7k). The product was synthesized following General Coupling Procedure D (See Supporting Info for intermediate). The crude residue was purified by flash chromatography on a silica gel column (eluent 90:10 EtOAc-MeOH) to give a white solid as a mixture of diastereomers $(63 \%) ; \mathrm{R}_{f}=0.55(90: 10 \mathrm{EtOAc}-\mathrm{MeOH}) ; \mathrm{mp}=107-111^{\circ} \mathrm{C}$; IR (neat) $\mathrm{cm}^{-1} 3258,3187,2929,1683,1598,1534,1449,1399,1372,906 ;{ }^{1} \mathrm{H}$ NMR (500 $\mathrm{MHz}$, Acetone- $\left.\mathrm{d}_{6}\right) \delta 9.42(\mathrm{~s}, 1 \mathrm{H}), 7.61(\mathrm{t}, \mathrm{J}=2.2 \mathrm{~Hz}, 1 \mathrm{H}), 7.27-7.21(\mathrm{~m}, 1 \mathrm{H}), 7.16$ (ddd, $\mathrm{J}=8.3,4.1,1.9 \mathrm{~Hz}, 1 \mathrm{H}), 4.24(\mathrm{ddd}, \mathrm{J}=14.7,8.7,2.1 \mathrm{~Hz}, 1 \mathrm{H}), 3.86-3.80(\mathrm{~m}, 3 \mathrm{H}), 3.46$ $-3.37(\mathrm{~m}, 1 \mathrm{H}), 3.23-3.15(\mathrm{~m}, 1 \mathrm{H}), 3.10-2.99(\mathrm{~m}, 1 \mathrm{H}), 2.36-2.18(\mathrm{~m}, 1 \mathrm{H}), 2.17-2.10$ (m, 1H), $2.09(\mathrm{~s}, 3 \mathrm{H}), 2.03-1.87(\mathrm{~m}, 4 \mathrm{H}), 1.86-1.80(\mathrm{~m}, 2 \mathrm{H}), 1.80-1.66(\mathrm{~m}, 1 \mathrm{H}), 1.55$ (dd, $\mathrm{J}=18.6,10.4 \mathrm{~Hz}, 1 \mathrm{H}), 1.38-1.32(\mathrm{~m}, 3 \mathrm{H}), 1.27(\mathrm{~s}, 3 \mathrm{H}), 0.87(\mathrm{~s}, 3 \mathrm{H})$; Carbon peaks are reported for the major rotamer of both diastereomers; a full ${ }^{13} \mathrm{C}$ spectrum plus HSQC are provided as Supporting Information. ${ }^{13} \mathrm{C}$ NMR (126 MHz, Acetone- $\left.d_{6}\right) \delta 24.37(2 \mathrm{C})$, 24.40 (2C), 26.87, 27.00, 27.27, 27.51, 27.62, 27.66, 28.03, 28.06, 29.36 (2C), 36.91, $36.98,38.82,38.83,40.68,40.74,47.37$ (2C), 47.75, 47.84, 52.87, 52.90, 55.99, 56.01, $77.65,77.88,84.83,84.96,103.13,103.18,111.56(2 C), 118.81,119.52,130.29,130.53$ $143.66,143.88,157.69,157.82,168.20,168.51,169.26,169.30$; Boron peak is reported 
for the major rotamer; full spectrum provided with rotamers integrated. ${ }^{11} \mathrm{~B}$ NMR (161 $\mathrm{MHz}$, Acetone) $\delta$ 26.62; HRMS (ESI+) $\mathrm{m} / z$ calcd for $\left[\mathrm{C}_{24} \mathrm{H}_{33} \mathrm{O}_{5} \mathrm{~N}_{2} \mathrm{~B}+\mathrm{Na}\right]^{+} 463.2375$, found 463.2391.

(2-amino-6-fluorophenyl)(2-((3aS,4S,6S,7aR)-3a,5,5-trimethylhexahydro-4,6methanobenzo[d][1,3,2]dioxaborol-2-yl)pyrrolidin-1-yl) methanone (12a). The product was synthesized following General Coupling Procedure C. The crude residue was purified by flash chromatography on a silica gel column (60:40 hexanes-EtOAc) to give a white solid (83\%). $\mathrm{R}_{f}=0.49$ (50:50 hexanes-EtOAc); $\mathrm{mp}=124-127^{\circ} \mathrm{C}$; IR (in $\mathrm{CDCl}_{3}$ ) $\mathrm{cm}^{-1} 3464,3357,2917,1623,1588,1443,1389,1376 ;{ }^{1} \mathrm{H}$ NMR $(500 \mathrm{MHz}$, Chloroformd) $\delta 7.05$ (tdd, $J=8.1,6.4,1.4 \mathrm{~Hz}, 1 \mathrm{H}$ ), $6.42(\mathrm{~d}, J=8.1 \mathrm{~Hz}, 1 \mathrm{H}), 6.38$ (dddd, $J=9.1,8.1$, 2.4, $0.8 \mathrm{~Hz}, 1 \mathrm{H}$ ), 4.41 (s, 2H), 4.34 (ddd, $J=20.5,8.8,2.1 \mathrm{~Hz}, 1 \mathrm{H}$ ), 3.42 (dddd, $J=10.9$, 8.0, 4.9, 3.1 Hz, 1H), $3.39-3.34(\mathrm{~m}, 2 \mathrm{H}), 2.33$ (dddd, $J=13.5,8.9,4.4,2.4 \mathrm{~Hz}, 1 \mathrm{H}), 2.25$ $-2.16(\mathrm{~m}, 1 \mathrm{H}), 2.16-2.07(\mathrm{~m}, 3 \mathrm{H}), 2.07-1.91(\mathrm{~m}, 3 \mathrm{H}), 1.92-1.82(\mathrm{~m}, 2 \mathrm{H}), 1.46(\mathrm{~d}, J$ $=25.0 \mathrm{~Hz}, 2 \mathrm{H}), 1.43-1.36(\mathrm{~m}, 2 \mathrm{H}), 1.28(\mathrm{~s}, 3 \mathrm{H}), 0.84(\mathrm{~s}, 3 \mathrm{H})$; Carbon peaks are reported for both diastereomers. ${ }^{13} \mathrm{C}$ NMR (126 MHz, Chloroform- $d$ ) $\delta 164.52,164.24,159.74$ (d, $J=245.0 \mathrm{~Hz}), 159.77(\mathrm{~d}, J=245.3 \mathrm{~Hz}), 146.68(\mathrm{~d}, J=6.9 \mathrm{~Hz}), 146.51(\mathrm{~d}, J=6.9 \mathrm{~Hz})$, $131.16(\mathrm{~d}, J=10.7 \mathrm{~Hz}), 131.07(\mathrm{~d}, J=10.7 \mathrm{~Hz}), 111.37(\mathrm{~d}, J=2.7 \mathrm{~Hz}), 111.31(\mathrm{~d}, J=2.7$ Hz), 109.87 (d, J = 22.1 Hz), 109.50 (d, J = 21.7 Hz), 104.29 (d, J = 11.1 Hz), $104.12(\mathrm{~d}$, $J=11.0 \mathrm{~Hz}), 85.99,85.94,78.09,77.91,51.55(2 \mathrm{C}), 47.43(\mathrm{~d}, J=3.7 \mathrm{~Hz}), 47.34(\mathrm{~d}, J=$ $3.8 \mathrm{~Hz}), 44.70,44.68,39.77,39.70,38.36,38.34,35.82,35.77,28.90,28.79,27.27$, $27.25,27.24,27.22,27.20,27.14,26.46,26.36,24.21(2 \mathrm{C}) ;{ }^{19} \mathrm{~F}$ NMR $(471 \mathrm{MHz}$ Chloroform- $d$ ) $\delta-115.11(\mathrm{t}, J=7.8 \mathrm{~Hz}),-115.35(\mathrm{t}, J=7.8 \mathrm{~Hz}) ;{ }^{11} \mathrm{~B} \mathrm{NMR}\left(161 \mathrm{MHz}, \mathrm{CDCl}_{3}\right)$ $\delta$ 30.43; HRMS (ESI+) $m / z$ calcd for $\left[\mathrm{C}_{21} \mathrm{H}_{28} \mathrm{O}_{3} \mathrm{~N}_{2} \mathrm{BF}+\mathrm{H}\right]^{+}$387.2250, found 387.2247. 
(2-aminophenyl)(2-((3aS,4S,6S,7aR)-3a,5,5-trimethylhexahydro-4,6-

methanobenzo[d][1,3,2]dioxaborol-2-yl)pyrrolidin-1-yl)methanone (12b). The product was synthesized following General Coupling Procedure C. The crude residue was purified by flash chromatography on a silica gel column (60:40 hexanes-EtOAc) to give the product as a yellow foam (89\%); $\mathrm{R}_{f}=0.38$ (50:50 hexanes-EtOAc); IR (in $\mathrm{CDCl}_{3}$ ) $\mathrm{cm}^{-1} 3468,3333,3067,2916,1617,1573,1534,1387,1370,1122,747 ;{ }^{1} \mathrm{H}$ NMR $(500$ $\mathrm{MHz}$, Chloroform- $d$ ) $\delta 7.24$ (ddd, $J=7.9,3.6,1.6 \mathrm{~Hz}, 1 \mathrm{H}), 7.18$ (dddd, $J=8.7,7.4,4.1$, $1.6 \mathrm{~Hz}, 1 \mathrm{H}), 6.71-6.65(\mathrm{~m}, 2 \mathrm{H}), 4.77(\mathrm{~s}, 2 \mathrm{H}), 4.32(\mathrm{ddd}, J=22.4,8.8,2.1 \mathrm{~Hz}, 1 \mathrm{H}), 3.60$ $-3.43(\mathrm{~m}, 2 \mathrm{H}), 3.28-3.16(\mathrm{~m}, 1 \mathrm{H}), 2.36(\mathrm{ddq}, J=13.3,9.0,2.0 \mathrm{~Hz}, 1 \mathrm{H}), 2.25-2.14(\mathrm{~m}$, 1H), $2.12-1.95(\mathrm{~m}, 4 \mathrm{H}), 1.94-1.78(\mathrm{~m}, 3 \mathrm{H}), 1.53-1.41(\mathrm{~m}, 4 \mathrm{H}), 1.30(\mathrm{~s}, 3 \mathrm{H}), 0.88(\mathrm{~s}$, $3 \mathrm{H})$; Carbon peaks are reported for both diastereomers. ${ }^{13} \mathrm{C} \mathrm{NMR}\left(126 \mathrm{MHz}, \mathrm{CDCl}_{3}\right) \delta$ $24.26,24.28,26.44,26.46,26.53,26.67,27.37,27.41,28.07,28.19,29.07,29.22,36.29$, $36.42,38.31,38.33,39.96,40.02,47.55,47.81,48.81$ (2C), 51.97, 52.05, 77.16, 77.25, $77.51,84.72,84.89,115.95,116.53,116.61,116.84,116.91,116.93,128.66,128.96$ 131.72, 132.00, 146.60, 146.93, 170.18, 170.62; ${ }^{11} \mathrm{~B}$ NMR $\left(161 \mathrm{MHz}, \mathrm{CDCl}_{3}\right) \delta 25.62$; HRMS (ESI+) $\mathrm{m} / \mathrm{z}$ calcd for $\left[\mathrm{C}_{21} \mathrm{H}_{29} \mathrm{O}_{3} \mathrm{~N}_{2} \mathrm{~B}+\mathrm{H}\right]^{+} 369.2344$, found 369.2343 .

\section{(2-fluorophenyl)(2-((3aS,4S,6S,7aR)-3a,5,5-trimethylhexahydro-4,6-}

methanobenzo[d][1,3,2]dioxaborol-2-yl)pyrrolidin-1-yl)methanone $\quad(12 c) . \quad$ The product was synthesized following General Coupling Procedure C. The crude residue was purified by flash chromatography on a silica gel column (eluent 70:30 hexanesEtOAc) to give a clear oil as a mixture of diastereomers (89\%); $R_{f}=0.26$ (70:30 hexanesEtOAc); IR (in $\mathrm{CDCl}_{3}$ ) $\mathrm{cm}^{-1} 3067,2921,1613,1584,1385,1374,1227,1195,753$; Proton coupling constants are reported for the major rotamer; a full ${ }^{1} \mathrm{H}$ spectrum with all rotamers 
integrated and HSQC are provided as Supporting Information. ${ }^{1} \mathrm{H}$ NMR $(500 \mathrm{MHz}$, Acetone- $\left.d_{6}\right) \delta 7.53-7.46(\mathrm{~m}, 1 \mathrm{H}), 7.43-7.36(\mathrm{~m}, 1 \mathrm{H}), 7.27(\mathrm{tt}, J=7.5,1.3 \mathrm{~Hz}, 1 \mathrm{H}), 7.21$

(ddt, $J=9.8,8.3,1.4 \mathrm{~Hz}, 1 \mathrm{H}$ ), 4.34 (ddd, $J=14.8,8.8,2.3 \mathrm{~Hz}, 1 \mathrm{H}$ ), 3.37 (ddt, $J=11.2$, 8.0, $4.1 \mathrm{~Hz}, 1 \mathrm{H}), 3.33-3.22(\mathrm{~m}, 1 \mathrm{H}), 3.24-3.10(\mathrm{~m}, 1 \mathrm{H}), 2.36$ (ddq, $J=13.9,8.9,2.4$ $H z, 1 H), 2.21-2.11(m, 1 H), 2.12-2.06(m, 1 H), 2.03-1.96(m, 2 H), 1.95-1.90(m$, $1 \mathrm{H}), 1.90-1.85(\mathrm{~m}, 1 \mathrm{H}), 1.85-1.64(\mathrm{~m}, 2 \mathrm{H}), 1.64-1.41(\mathrm{~m}, 1 \mathrm{H}), 1.41-1.20(\mathrm{~m}, 6 \mathrm{H})$, $1.01-0.78(\mathrm{~m}, 3 \mathrm{H}) ;$ Carbon peaks are reported for the major rotamer of both diastereomers. ${ }^{13} \mathrm{C}$ NMR $\left(126 \mathrm{MHz}\right.$, Acetone- $\left.d_{6}\right) \delta 164.92,164.79,159.32(2 \mathrm{C}, \mathrm{d}, J=$ $246.8 \mathrm{~Hz}), 132.29$ (d, J = 8.3 Hz), 132.19 (d, $J=8.0 \mathrm{~Hz}), 130.07$ (d, $J=4.1 \mathrm{~Hz}), 129.95$ $(\mathrm{d}, J=4.0 \mathrm{~Hz}), 126.23(\mathrm{~d}, J=17.9 \mathrm{~Hz}), 126.03(\mathrm{~d}, J=17.8 \mathrm{~Hz}), 125.41,125.38,116.71$, 116.54, 86.10, 86.07, 78.42, 78.27, 52.43, 52.39, 48.37 (d, $J=3.3 \mathrm{~Hz}), 48.26$ (d, J = 3.6 Hz), 45.38 (2C), 40.49, 40.46, 38.92, 38.91, 36.42, 36.39, 30.24, 30.09, 29.15, 29.02, $28.00,27.78,27.73,27.50,26.85,26.83,24.30(2 \mathrm{C})$; ; Fluorine peaks are reported for the major rotamer; full spectrum provided with rotamers integrated as Supporting Information. ${ }^{19} \mathrm{~F}$ NMR $\left(471 \mathrm{MHz}\right.$, Acetone- $\left.d_{6}\right) \delta-116.21(\mathrm{dt}, J=9.5,6.2 \mathrm{~Hz}),-116.45(\mathrm{dt}, J=10.1,6.1$ $\mathrm{Hz}$ ); Boron peak is reported for the major rotamer; full spectrum provided with rotamers integrated as Supporting Information. ${ }^{11} \mathrm{~B} \mathrm{NMR}\left(161 \mathrm{MHz}, \mathrm{CDCl}_{3}\right) \delta 30.26$; HRMS (ESI+) $\mathrm{m} / \mathrm{z}$ calcd for $\left[\mathrm{C}_{21} \mathrm{H}_{27} \mathrm{O}_{3} \mathrm{NBF}+\mathrm{Na}\right]^{+} 394.1960$, found 394.1966 .

(2,6-difluorophenyl)(2-((3aS,4S,6S,7aR)-3a,5,5-trimethylhexahydro-4,6methanobenzo[d][1,3,2]dioxaborol-2-yl)pyrrolidin-1-yl)methanone (12d). The product was synthesized following General Coupling Procedure C. The crude residue was purified by flash chromatography on a silica gel column (eluent 70:30 hexanesEtOAc) to give a clear oil as a mixture of diastereomers (94\%); $R_{f}=0.50$ (70:30 hexanes- 


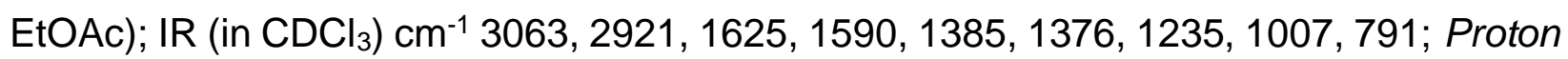
coupling constants are reported for the major rotamer; a full ${ }^{1} \mathrm{H}$ spectrum with all rotamers integrated and HSQC are provided as Supporting Information; ${ }^{1} \mathrm{H}$ NMR $(500 \mathrm{MHz}$, Acetone- $\left.d_{6}\right) \delta 7.60-7.41(\mathrm{~m}, 1 \mathrm{H}), 7.14-7.05(\mathrm{~m}, 2 \mathrm{H}), 4.35$ (ddd, $J=14.0,8.9,2.2 \mathrm{~Hz}$, $1 \mathrm{H}), 3.99-3.28(\mathrm{~m}, 2 \mathrm{H}), 3.27-3.18(\mathrm{~m}, 1 \mathrm{H}), 2.41-2.30(\mathrm{~m}, 1 \mathrm{H}), 2.30-2.08(\mathrm{~m}, 2 \mathrm{H})$, $2.04-2.00(\mathrm{~m}, 1 \mathrm{H}), 2.00-1.95(\mathrm{~m}, 1 \mathrm{H}), 1.95-1.89(\mathrm{~m}, 1 \mathrm{H}), 1.89-1.61(\mathrm{~m}, 3 \mathrm{H}), 1.59$ $-1.40(\mathrm{~m}, 1 \mathrm{H}), 1.40-1.23(\mathrm{~m}, 6 \mathrm{H}), 1.03-0.79(\mathrm{~m}, 3 \mathrm{H})$; Carbon peaks are reported for the major rotamer of both diastereomers ${ }^{13} \mathrm{C}$ NMR $\left(126 \mathrm{MHz}\right.$, Acetone- $\left.d_{6}\right) \delta 159.79(\mathrm{~d}, J$ $=248.5 \mathrm{~Hz}), 159.73(\mathrm{~d}, J=248.5 \mathrm{~Hz}), 159.59,159.51,132.20(\mathrm{t}, J=9.8 \mathrm{~Hz}), 116.08(\mathrm{t}, J$ $=23.8 \mathrm{~Hz}), 112.73(2 \mathrm{C}, \mathrm{d}, J=3.6 \mathrm{~Hz}), 112.56(2 \mathrm{C}, \mathrm{d}, J=3.6 \mathrm{~Hz}), 86.39,86.33,78.57$, $78.43,52.31,52.26,48.05,47.95,44.95,44.58,40.39$ (2C), 38.92, 38.90, 36.25, 36.19, 29.06, 28.94, 28.27, 27.97, 27.52 (2C), 27.47 (2C), 26.85, 26.80, 24.28 (2C); All fluorine peaks are reported; full spectrum provided with rotamers integrated as Supporting Information; Broad F-B interaction peaks also observed ${ }^{19} \mathrm{~F}$ NMR $\left(471 \mathrm{MHz}\right.$, Acetone- $\left.d_{6}\right)$ $\delta-110.34--110.47(m),-111.01--111.12(m),-114.85--115.03(m),-115.13--115.24$ (m); ${ }^{11} \mathrm{~B}$ NMR (161 MHz, Acetone) $\delta$ 31.62; ; HRMS (ESI+) $\mathrm{m} / \mathrm{z}$ calcd for $\left[\mathrm{C}_{21} \mathrm{H}_{26} \mathrm{O}_{3} \mathrm{NBF}_{2}\right.$ $+\mathrm{Na}]^{+}$412.1866, found 412.1873 .

\section{Phenyl(2-((3aS,4S,6S,7aR)-3a,5,5-trimethylhexahydro-4,6-}

methanobenzo[d][1,3,2]dioxaborol-2-yl)pyrrolidin-1-yl)methanone $\quad(12 e) . \quad$ The product was synthesized following General Coupling Procedure C. The crude residue was purified by flash chromatography on a silica gel column (eluent 50:50 hexanesEtOAc) to give a clear oil as a mixture of diastereomers $(77 \%) ; R_{f}=0.33$ (50:50 hexanesEtOAc); IR (in $\left.\mathrm{CDCl}_{3}\right) \mathrm{cm}^{-1} 3063,2921,1603,1592,1385,1372,1122,1080,698 ;{ }^{1} \mathrm{H}$ 
$\operatorname{NMR}\left(500 \mathrm{MHz}\right.$, Acetone- $\left.d_{6}\right) \delta 7.70-7.34(\mathrm{~m}, 5 \mathrm{H}), 4.35-4.20(\mathrm{~m}, 1 \mathrm{H}), 3.74-3.58(\mathrm{~m}$, 1H), $3.54-3.44(m, 1 H), 3.18-3.01(m, 1 H), 2.43-2.28(m, 1 H), 2.28-2.07(m, 1.4 H)$, $2.03-1.94(\mathrm{~m}, 2.6 \mathrm{H}), 1.94-1.80(\mathrm{~m}, 2 \mathrm{H}), 1.79-1.66(\mathrm{~m}, 1 \mathrm{H}), 1.64-1.50(\mathrm{~m}, 1 \mathrm{H}), 1.49$ $-1.31(\mathrm{~m}, 3 \mathrm{H}), 1.30-1.24(\mathrm{~m}, 3 \mathrm{H}), 1.23-1.05(\mathrm{~m}, 1 \mathrm{H}), 0.95-0.74(\mathrm{~m}, 3 \mathrm{H}) ;$ Carbon peaks are reported for the major rotamer of both diastereomers. ${ }^{13} \mathrm{C} N \mathrm{NMR}(126 \mathrm{MHz}$, Acetone- $\left.d_{6}\right) \delta 23.48,23.51,25.98,26.08,26.14,26.36,26.72,26.75,27.82,27.88,28.44$, $28.58,36.02,36.03,37.95,39.78,39.83,47.10,48.44,48.49,51.95,51.96,76.83,77.02$ 84.09, 84.18, 127.92 (2C), 128.11 (2C), 128.23 (2C), 128.25 (2C), 130.59, 130.77, 133.87, 134.35, 169.04, 169.28; ${ }^{11} \mathrm{~B}$ NMR (161 MHz, Acetone- $\left.d_{6}\right) \delta$ 26.68; HRMS (ESI+) $\mathrm{m} / \mathrm{z}$ calcd for $\left[\mathrm{C}_{21} \mathrm{H}_{28} \mathrm{O}_{3} \mathrm{NB}+\mathrm{Na}\right]^{+} 376.2054$, found 376.2067 .

(2-fluoro-6-methoxyphenyl)(2-((3aS,4S,6S,7aR)-3a,5,5-trimethylhexahydro-4,6methanobenzo[d][1,3,2]dioxaborol-2-yl)pyrrolidin-1-yl)methanone

(12f). The product was synthesized following General Coupling Procedure C. The crude residue was purified by flash chromatography on a silica gel column (eluent 50:50 hexanesEtOAc) to give a clear oil as a mixture of diastereomers $(75 \%) . \mathrm{R}_{f}=0.34$ (50:50 hexanesEtOAc); IR (neat) $\mathrm{cm}^{-1} 3004,2913,1740,1615,1471,1389,1376,1080,908 ;{ }^{1} \mathrm{H}$ NMR $\left(500 \mathrm{MHz}\right.$, Acetone- $\left.d_{6}\right) \delta 7.37$ (tdd, $\left.J=8.4,6.7,2.2 \mathrm{~Hz}, 1 \mathrm{H}\right), 6.89(\mathrm{~d}, J=8.4 \mathrm{~Hz}, 1 \mathrm{H})$, $6.81-6.66(\mathrm{~m}, 1 \mathrm{H}), 4.38-4.08(\mathrm{~m}, 1 \mathrm{H}), 3.98-3.81(\mathrm{~m}, 3 \mathrm{H}), 3.76-3.20(\mathrm{~m}, 2 \mathrm{H}), 3.15$ $(\mathrm{q}, J=8.8 \mathrm{~Hz}, 1 \mathrm{H}), 2.41-2.30(\mathrm{~m}, 1 \mathrm{H}), 2.30-2.11(\mathrm{~m}, 1 \mathrm{H}), 2.11-2.06(\mathrm{~m}, 1 \mathrm{H}), 2.04-$ $1.97(\mathrm{~m}, 2 \mathrm{H}), 1.95-1.65(\mathrm{~m}, 4 \mathrm{H}), 1.64-1.42(\mathrm{~m}, 1 \mathrm{H}), 1.40-1.33(\mathrm{~m}, 2 \mathrm{H}), 1.32-1.16$ $(\mathrm{m}, 4 \mathrm{H}), 1.04-0.78(\mathrm{~m}, 3 \mathrm{H}) ;$ Carbon peaks are reported for the major rotamer of both diastereomers; a full ${ }^{13} \mathrm{C}$ spectrum plus HSQC are provided as Supporting Information. ${ }^{13} \mathrm{C}$ NMR (126 MHz, Acetone- $\left.d_{6}\right) \delta 162.17,162.02,160.00$ (2C, d, J = 245.0 Hz), 158.36, 
$158.05,131.51(\mathrm{~d}, J=10.1 \mathrm{~Hz}), 131.47(\mathrm{~d}, J=10.2 \mathrm{~Hz}), 116.37,116.22,108.73(\mathrm{~d}, J=$ $22.2 \mathrm{~Hz}$ ), 108.66 (d, $J=21.7 \mathrm{~Hz}), 108.04(2 \mathrm{C}), 86.13,86.03,78.45,78.29,56.60(2 \mathrm{C})$, 52.39, 52.36, 47.61, 47.49, 44.48 (2C), 40.46, 40.44, 38.90 (d, J = 4.2 Hz), 38.87 (d, J = 3.1 Hz), 36.30, 36.22, 29.14, 28.96, 28.30, 27.99, 27.61, 27.52, 27.51 (2C), 26.87, 26.81, 24.30 (2C); Fluorine peaks are reported for the major rotamer; full spectrum provided with rotamers integrated as Supporting Information. ${ }^{19} \mathrm{~F}$ NMR $\left(471 \mathrm{MHz}\right.$, Acetone- $\left.d_{6}\right) \delta$ $112.70(\mathrm{dd}, J=8.3,6.6 \mathrm{~Hz}),-113.41(\mathrm{dd}, J=8.6,6.7 \mathrm{~Hz}) ;{ }^{11} \mathrm{~B}$ NMR $\left(161 \mathrm{MHz}, \mathrm{CDCl}_{3}\right) \delta$ 22.45; HRMS (ESI+) $m / z$ calcd for $\left[\mathrm{C}_{22} \mathrm{H}_{29} \mathrm{O}_{4} \mathrm{NFB}+\mathrm{Na}\right]^{+} 424.2066$, found 424.2079.

(2-methoxyphenyl)(2-((3aS,4S,6S,7a R)-3a,5,5-trimethylhexahydro-4,6methanobenzo[d][1,3,2]dioxaborol-2-yl)pyrrolidin-1-yl)methanone (12g). The product was synthesized following General Coupling Procedure C. The crude residue was purified by flash chromatography on a silica gel column (eluent 60:40 hexanesEtOAc) to give a clear oil as a mixture of diastereomers $(75 \%) . \mathrm{R}_{f}=0.50$ (60:40 hexanesEtOAc); IR (neat) $\mathrm{cm}^{-1} 3067,2917,1601,1566,1385,1373,1253,1021,753 ;{ }^{1} \mathrm{H}$ NMR (500 MHz, Acetone- $\left.d_{6}\right) \delta 7.50-7.32(\mathrm{~m}, 1 \mathrm{H}), 7.31-7.17(\mathrm{~m}, 1 \mathrm{H}), 7.16-7.05(\mathrm{~m}, 1 \mathrm{H})$, $7.02-6.85(\mathrm{~m}, 1 \mathrm{H}), 4.39-4.03(\mathrm{~m}, 1 \mathrm{H}), 4.00-3.79(\mathrm{~m}, 3 \mathrm{H}), 3.72-3.13(\mathrm{~m}, 2 \mathrm{H}), 3.13$ $-3.05(\mathrm{~m}, 1 \mathrm{H}), 2.46-2.29(\mathrm{~m}, 1 \mathrm{H}), 2.28-2.07(\mathrm{~m}, 1 \mathrm{H}), 2.04-1.93(\mathrm{~m}, 3 \mathrm{H}), 1.92-1.87$ $(\mathrm{m}, 1 \mathrm{H}), 1.86-1.77(\mathrm{~m}, 2 \mathrm{H}), 1.76-1.55(\mathrm{~m}, 1 \mathrm{H}), 1.55-1.33(\mathrm{~m}, 3 \mathrm{H}), 1.32-1.23(\mathrm{~m}$, $3 \mathrm{H}), 1.23-1.16(\mathrm{~m}, 1 \mathrm{H}), 0.98-0.78(\mathrm{~m}, 3 \mathrm{H})$; Carbon peaks are reported for the major rotamer of both diastereomers; a full ${ }^{13} \mathrm{C}$ spectrum plus HSQC are provided as Supporting Information. ${ }^{13} \mathrm{C}$ NMR (126 MHz, Acetone-d $\left.d_{6}\right) \delta 24.34,24.36,26.83,26.91,27.54,27.56$, $27.59,27.78,27.90,27.91,29.16,29.33,36.64,36.66,38.87$ (2C), 40.56, 40.62, 45.97, $46.37,47.62,47.75,52.64$ (2C), 56.10, 56.13, 77.94, 78.14, 85.39, 85.51, 112.50, 112.51, 
121.36 (2C), 126.29, 126.79, 129.33, 129.48, 131.62, 131.81, 156.80, 156.86, 167.69, 167.94; ${ }^{11} \mathrm{~B}$ NMR (161 MHz, Acetone- $\left.d_{6}\right) \delta$ 29.19; HRMS (ESI+) $\mathrm{m} / \mathrm{z}$ calcd for $\left[\mathrm{C}_{22} \mathrm{H}_{30} \mathrm{O}_{4} \mathrm{NB}+\mathrm{Na}\right]^{+} 406.2160$, found 406.2160 .

(2-(methylthio)phenyl)(2-((3aS,4S,6S,7aR)-3a,5,5-trimethylhexahydro-4,6methanobenzo[d][1,3,2]dioxaborol-2-yl)pyrrolidin-1-yl)methanone (12h). The product was synthesized following General Coupling Procedure C. The crude residue was purified by flash chromatography on a silica gel column (eluent 60:40 hexanesEtOAc) to give a clear oil as a mixture of diastereomers $(97 \%) . R_{f}=0.46(60: 40$ hexanesEtOAc); IR (in $\mathrm{CHCl}_{3}$ ) $\mathrm{cm}^{-1} 3055,2921,1611,1590,1385,1376,1203,1031 ;{ }^{1} \mathrm{H}$ NMR $\left(500 \mathrm{MHz}\right.$, Acetone- $\left.d_{6}\right) \delta 7.45-7.27(\mathrm{~m}, 2 \mathrm{H}), 7.29-7.13(\mathrm{~m}, 2 \mathrm{H}), 4.39-4.03(\mathrm{~m}, 1 \mathrm{H})$, $3.99-3.09(\mathrm{~m}, 3 \mathrm{H}), 2.60-2.41(\mathrm{~m}, 3 \mathrm{H}), 2.40-2.29(\mathrm{~m}, 1 \mathrm{H}), 2.28-2.11(\mathrm{~m}, 1 \mathrm{H}), 2.10$ $-2.03(\mathrm{~m}, 1 \mathrm{H}), 2.02-1.91(\mathrm{~m}, 2 \mathrm{H}), 1.91-1.87(\mathrm{~m}, 1 \mathrm{H}), 1.87-1.80(\mathrm{~m}, 2 \mathrm{H}), 1.80-1.58$ $(\mathrm{m}, 1 \mathrm{H}), 1.58-1.35(\mathrm{~m}, 3 \mathrm{H}), 1.35-0.99(\mathrm{~m}, 4 \mathrm{H}), 0.99-0.79(\mathrm{~m}, 3 \mathrm{H})$; Carbon peaks are reported for the major rotamer of the two diastereomers; a full ${ }^{13} \mathrm{C}$ spectrum plus HSQC are provided as Supporting Information. ${ }^{13} \mathrm{C}$ NMR $\left(126 \mathrm{MHz}\right.$, Acetone- $\left.d_{6}\right) \delta 16.07,16.14$, 24.31 (2C), 26.80, 26.91, 27.51, 27.52, 27.86, 28.00, 28.02, 28.09, 29.01, 29.24, 29.84, 36.40 (2C), 38.88, 38.90, 40.45, 40.49, 44.96 (2C), 48.31, 48.38, 52.41, 52.45, 78.19, $78.38,85.96,86.03,126.05,126.09,127.58,127.64,127.72,127.89,130.16,130.21$, 136.27, 136.32, 138.15, 138.27, 167.98, 168.17; ${ }^{11} \mathrm{~B}$ NMR (161 MHz, Acetone- $\left.d_{6}\right) \delta$ 30.96; HRMS (ESI+) $\mathrm{m} / z$ calcd for $\left[\mathrm{C}_{22} \mathrm{H}_{30} \mathrm{O}_{3} \mathrm{NBS}+\mathrm{H}\right]^{+} 400.2112$, found 400.2108 .

General Procedure for boronic ester deprotection. The boronic ester was dissolved in $\mathrm{DCM}(0.1 \mathrm{M})$, and the solution was cooled to $-78^{\circ} \mathrm{C} . \mathrm{BCl}_{3}(2 \mathrm{M}$ in $\mathrm{DCM}, 5$ eq) was added dropwise, and the reaction stirred at $-78^{\circ} \mathrm{C}$ for 1 hour (or at room temperature overnight 
for 12i). The solvent and excess $\mathrm{BCl}_{3}$ were removed in vacuo and co-evaporated several times with anhydrous DCM. The resultant brown residue was dissolved in $\mathrm{H}_{2} \mathrm{O}$ and DCM, and the product was extracted with $\mathrm{H}_{2} \mathrm{O}$. The combined aqueous layers were washed with $\mathrm{Et}_{2} \mathrm{O}$ and $\mathrm{EtOAc}$ and concentrated in vacuo to give the products as solids. In the case of $7 \mathbf{e}$ and $\mathbf{7 j}$, deacetylated product can be re-acetylated by dissolving the solid in $\mathrm{H}_{2} \mathrm{O}$ (0.1 M final solution), adding $\mathrm{Ac}_{2} \mathrm{O}$ (10 eq), and sonicating the solution (with a balloon to trap $\mathrm{AcOH}$ vapors and prevent pressure build-up) for 30 minutes. The solution can then be concentrated in vacuo to give the final acetylated product.

(1-(4-acetamidobenzoyl)pyrrolidin-2-yl)boronic acid (7e) The product was isolated as a white solid $(91 \%) . \mathrm{R}_{f}=$ does not elute on silica-backed TLC plates; $\mathrm{mp}=$ compound does not melt, decomposes $>250^{\circ} \mathrm{C}$; IR (neat) $\mathrm{cm}^{-1} 3202,3009,2865,1681,1598,1443$, 1194, 797; ${ }^{1} \mathrm{H}$ NMR (500 MHz, DMSO- $\left.d_{6}\right) \delta 10.52(\mathrm{~s}, 1 \mathrm{H}), 7.85$ (d, J=8.7 Hz, 2H), 7.80 (d, $J=8.7 \mathrm{~Hz}, 2 \mathrm{H}), 4.02-3.94(\mathrm{~m}, 1 \mathrm{H}), 3.48(\mathrm{dt}, J=11.6,8.1 \mathrm{~Hz}, 1 \mathrm{H}), 2.86(\mathrm{dd}, J=11.9$, $6.4 \mathrm{~Hz}, 1 \mathrm{H}), 2.20-2.10(\mathrm{~m}, 2 \mathrm{H}), 2.09(\mathrm{~s}, 3 \mathrm{H}), 1.76(\mathrm{dt}, J=13.0,6.7 \mathrm{~Hz}, 1 \mathrm{H}), 1.48(\mathrm{qd}, J$ $=11.8,7.8 \mathrm{~Hz}, 1 \mathrm{H}) ;{ }^{13} \mathrm{C}$ NMR $(126 \mathrm{MHz}$, DMSO-d $) \delta$ 169.53, 169.34, 144.43, 131.23 (2C), 119.26, 118.51 (2C), 58.68, 47.77, 28.92, 24.52, 24.27; ${ }^{11} \mathrm{~B}$ NMR (161 MHz, DMSOd6) $\delta$ 20.03; HRMS (ESI+) $\mathrm{m} / \mathrm{z}$ calcd for $\left[\mathrm{C}_{13} \mathrm{H}_{17} \mathrm{BN}_{2} \mathrm{O}_{4}+\mathrm{Na}\right]^{+} 299.1174$, found 299.1177. (1-(4-acetamido-2-fluorobenzoyl)pyrrolidin-2-yl)boronic acid (7j) The product was isolated as a white solid (71\%). $R_{f}=$ does not elute on silica-backed TLC plates; $\mathrm{mp}=$ compound does not melt, decomposes $>250^{\circ} \mathrm{C}$; IR (neat) $\mathrm{cm}^{-1} 3198,2976,1695,1623$, 1604, 1419, 1247, 880; ${ }^{1} \mathrm{H}$ NMR (500 MHz, DMSO-d6) $\delta 10.59$ (s, 1H), 7.79 (dd, $J=13.7$, $2.0 \mathrm{~Hz}, 1 \mathrm{H}$ ), 7.70 (t, $J=8.4 \mathrm{~Hz}, 1 \mathrm{H}), 7.44(\mathrm{dd}, J=8.7,2.0 \mathrm{~Hz}, 1 \mathrm{H}$ ), 3.68 (dt, $J=12.9,7.0$ $\mathrm{Hz}, 1 \mathrm{H}), 3.35(\mathrm{dt}, J=11.8,7.8 \mathrm{~Hz}, 1 \mathrm{H}), 2.87(\mathrm{dd}, J=11.5,6.9 \mathrm{~Hz}, 1 \mathrm{H}), 2.18-1.98(\mathrm{~m}$, 
$5 \mathrm{H}), 1.80(\mathrm{dq}, J=11.9,5.6 \mathrm{~Hz}, 1 \mathrm{H}), 1.55(\mathrm{tt}, J=12.0,9.6 \mathrm{~Hz}, 1 \mathrm{H}) ;{ }^{13} \mathrm{C}$ NMR $(126 \mathrm{MHz}$, DMSO-d6) $\delta$ 169.67, 167.19, $160.43(\mathrm{~d}, J=253.2 \mathrm{~Hz}), 146.06(\mathrm{~d}, J=12.2 \mathrm{~Hz}), 132.14$, 114.92, 107.95 (d, $J=12.2 \mathrm{~Hz}), 105.93$ (d, $J=26.9 \mathrm{~Hz}), 57.67,47.11(\mathrm{~d}, J=5.6 \mathrm{~Hz}$ ), $27.85,24.75,24.31 ;{ }^{19} \mathrm{~F}$ NMR $\left(471 \mathrm{MHz}, \mathrm{DMSO}-d_{6}\right) \delta-106.79(\mathrm{dd}, J=13.9,8.2 \mathrm{~Hz}) ;{ }^{11} \mathrm{~B}$ NMR (161 MHz, DMSO) $\delta$ 19.99; HRMS (ESI+) $\mathrm{m} / \mathrm{z}$ calcd for $\left[\mathrm{C}_{13} \mathrm{H}_{16} \mathrm{BFN}_{2} \mathrm{O}_{4}+\mathrm{Na}\right]^{+}$ 317.1079 , found 317.1086 .

(1-(2-amino-6-fluorobenzoyl)pyrrolidin-2-yl)boronic acid (12i) The product was isolated as a beige solid, which was triturated in $\mathrm{Et}_{2} \mathrm{O}$ and filtered under vacuum to give the product as a beige solid (57\%). Rf: does not elute on silica-backed TLC plates; $\mathrm{mp}=$ compound does not melt, decomposes $>250^{\circ} \mathrm{C}$; IR (neat) $\mathrm{cm}^{-1} 3198,2964,1635,1615$, 1443, 1400, 1191, 789, 709; (NMR peaks are reported for both rotamers, ratio $~ 7: 3)^{1} \mathrm{H}$ NMR (500 MHz, DMSO- $\left.d_{6}\right) \delta 8.16(\mathrm{~s}, 2 \mathrm{H}), 7.45(\mathrm{td}, J=8.2,5.7 \mathrm{~Hz}, 0.7 \mathrm{H}), 7.29(\mathrm{td}, J=$ 8.2, $6.5 \mathrm{~Hz}, 0.3 \mathrm{H}), 7.16(\mathrm{t}, J=9.2 \mathrm{~Hz}, 0.7 \mathrm{H}), 7.08(\mathrm{~d}, J=7.8 \mathrm{~Hz}, 0.7 \mathrm{H}), 6.63(\mathrm{~d}, J=8.4$ $\mathrm{Hz}, 0.3 \mathrm{H}), 6.45(\mathrm{dd}, J=10.8,8.1 \mathrm{~Hz}, 0.3 \mathrm{H}), 3.55(\mathrm{dt}, J=13.0,6.9 \mathrm{~Hz}, 0.3 \mathrm{H}), 3.51-3.38$ (m, 1.4H), $3.21(\mathrm{dt}, J=12.2,7.9 \mathrm{~Hz}, 0.3 \mathrm{H}), 2.88(\mathrm{dd}, J=11.4,6.9 \mathrm{~Hz}, 0.3 \mathrm{H}), 2.43(\mathrm{dd}, J$ = 9.3, 3.3 Hz, 0.7H), $2.07-1.96(\mathrm{~m}, 1 \mathrm{H}), 1.84-1.77(\mathrm{~m}, 1 \mathrm{H}), 1.77-1.69(\mathrm{~m}, 1 \mathrm{H}), 1.64$ - $1.52(\mathrm{~m}, 1 \mathrm{H}) ;{ }^{13} \mathrm{C}$ NMR (126 MHz, DMSO-d6) $\delta 166.93$ (0.3C), 160.74 (d, J=249.0 Hz), 159.60 (d, $J=251.40 \mathrm{~Hz}$ ), $158.71(0.7 \mathrm{C}), 150.25$ (d, $J=4.7 \mathrm{~Hz}, 0.3 \mathrm{C}), 136.00$ (d, J= 5.0 $\mathrm{Hz}, 0.7 \mathrm{C}), 134.95(\mathrm{~d}, J=11.0 \mathrm{~Hz}, 0.3 \mathrm{C}), 131.30(\mathrm{~d}, J=9.6 \mathrm{~Hz}, 0.7 \mathrm{C}), 120.01$ (d, $J=15.8$ $\mathrm{Hz}, 0.7 \mathrm{C}), 119.27(0.7 \mathrm{C}), 114.16(\mathrm{~d}, J=21.8 \mathrm{~Hz}, 0.7 \mathrm{C}), 112.12(0.3 \mathrm{C}), 101.85$ (d, J = $21.8 \mathrm{~Hz}, 0.3 \mathrm{C}$ ), 97.39 (d, $J=16.6 \mathrm{~Hz}, 0.3 \mathrm{C}$ ), $46.45(\mathrm{~d}, J=5.0 \mathrm{~Hz}), 51.33(0.7 \mathrm{C}), 56.11$ (0.3C), 46.45 (d, J = 5.0 Hz, 0.3C), 46.14 (0.7C), 27.61 (0.3C), 26.54 (0.7C), 24.71 (0.3C), $24.21(0.7 \mathrm{C}) ;{ }^{19} \mathrm{~F}$ NMR (471 MHz, DMSO- $\left.d_{6}\right) \delta-111.45$ (dd, $\left.J=11.0,6.8 \mathrm{~Hz}, 0.3 \mathrm{~F}\right),-$ 
$113.24(\mathrm{dd}, J=10.1,5.8 \mathrm{~Hz}, 0.7 \mathrm{~F}) .{ }^{11} \mathrm{~B}$ NMR $(161 \mathrm{MHz}, \mathrm{DMSO}) \delta$ 19.97; HRMS (ESI+)

$\mathrm{m} / \mathrm{z}$ calcd for $\left[\mathrm{C}_{11} \mathrm{H}_{14} \mathrm{BFN}_{2} \mathrm{O}_{3}+\mathrm{Na}\right]^{+} 275.0974$, found 275.0968 .

\section{Supplementary material.}

NMR spectra; table of purities for biologically tested compounds; curves and equations corresponding to biological data.

\section{Acknowledgment}

We thank CIHR for funding (Operating Grant to NM and AKM - MOP 136943). JP was supported by a McGill University Molson and Hilton Hart Fellowship in Science, CD was supported by an NSERC scholarship.

\section{References}

[1] American Cancer Society: Cancer Facts and Figures, in, American Cancer Society, Inc., 2017.

[2] V.J. Christiansen, K.W. Jackson, K.N. Lee, T.D. Downs, P.A. McKee, Targeting Inhibition of Fibroblast Activation Protein- $\alpha$ and Prolyl Oligopeptidase Activities on Cells Common to Metastatic Tumor Microenvironments, Neoplasia, 15 (2013) 348-358.

[3] J.A. Joyce, D.T. Fearson, T cell exclusion, immune privilege, and the tumor microenvironment, Science, 348 (2015) 74-80.

[4] F. Spill, D.S. Reynolds, R.D. Kamm, M.H. Zaman, Impact of the physical microenvironment on tumor progression and metastasis, Curr. Opin. Biotechnol., 40 (2016) 41-48.

[5] T. Kelly, Y. Huang, A.E. Simms, A. Mazur, Fibroblast Activation Protein-a. A Key Modulator of the Microenvironment in Multiple Pathologies, in, 2012, pp. 83-116.

[6] A.M. Santos, J. Jung, N. Aziz, J.L. Kissil, E. Puré, Targeting fibroblast activation protein inhibits tumor stromagenesis and growth in mice, J. Clin. Invest., 119 (2009) 3613-3625. [7] O.E. Franco, S.W. Hayward, Targeting the Tumor Stroma as a Novel Therapeutic Approach for Prostate Cancer, Adv. Pharmacol., 65 (2012) 267-313.

[8] R. Liu, H. Li, L. Liu, J. Yu, X. Ren, Fibroblast activation protein: A potential therapeutic target in cancer, Cancer Biol. Ther., 13 (2012) 123-129. 
[9] S. Koontongkaew, The Tumor Microenvironment Contribution to Development, Growth, Invasion and Metastasis of Head and Neck Squamous Cell Carcinomas, J. Cancer, 4 (2013) 66-83.

[10] J. Barar, Targeting Tumor Microenvironment: The Key Role of Immune System, Biolmpacts, 2 (2012) 1-3.

[11] S.Y. Sung, C.L. Hsieh, D. Wu, L.W.K. Chung, P.A.S. Johnstone, Tumor Microenvironment Promotes Cancer Progression, Metastasis, and Therapeutic Resistance, Curr. Prob. Cancer, 31 (2007) 36-100.

[12] V.J. Christiansen, K.W. Jackson, K.N. Lee, T.D. Downs, P.A. McKee, Targeting Inhibition of Fibroblast Activation Protein-alpha and Prolyl Oligopeptidase Activities on Cells Common to Metastatic Tumor Microenvironments Neoplasia, 15 (2013).

[13] F. Zi, J. He, D. He, Y. Li, L. Yang, Z. Cai, Fibroblast activation protein alpha in tumor microenvironment: recent progression and implications (review), Mol. Med. Rep., 11 (2015) 3203-3211.

[14] T.T. Myohanen, J. Tenorio-Laranga, B. Jokinen, R. Vazquez-Sanchez, M.J. MorenoBaylach, J.A. Garcia-Horsman, P.T. Mannisto, Prolyl oligopeptidase induces angiogenesis both in vitro and in vivo in a novel regulatory manner, $\mathrm{Br}$. J. Pharmacol., 163 (2011) 1666-1678.

[15] P.T. Männistö, J.A. García-Horsman, Mechanism of Action of Prolyl Oligopeptidase (PREP) in Degenerative Brain Diseases: Has Peptidase Activity Only a Modulatory Role on the Interactions of PREP with Proteins? Front. Aging Neurosci., 9 (2017) 27.

[16] M.J. Hannula, T.T. Myöhänen, J. Tenorio-Laranga, P.T. Männistö, J.A. GarciaHorsman, Prolyl oligopeptidase colocalizes with $\alpha$-synuclein, $\beta$-amyloid, tau protein and astroglia in the post-mortem brain samples with Parkinson's and Alzheimer's diseases, Neuroscience, 242 (2013) 140-150.

[17] R. Svarcbahs, U.H. Julku, S. Norrbacka, T.T. Myöhänen, Removal of prolyl oligopeptidase reduces alpha-synuclein toxicity in cells and in vivo, Sci. Rep., 8 (2018) 1552.

[18] J. Lawandi, Gerber-Lemaire, S., Juillerat-Jeanneret, L., Moitessier, N., Inhibitors of Prolyl Oligopeptidases for the Therapy of Human Diseases: Defining Diseases and Inhibitors, J. Med. Chem., 53 (2010) 3423-3438.

[19] K.W. Jackson, V.J. Christiansen, V.R. Yadav, R. Silasi-Mansat, F. Lupu, V. Awasthi, R.R. Zhang, P.A. McKee, Suppression of Tumor Growth in Mice by Rationally Designed Pseudopeptide Inhibitors of Fibroblast Activation Protein and Prolyl Oligopeptidase, Neoplasia, 17 (2015) 43-54.

[20] V. Teichgraber, C. Monasterio, K. Chaitanya, R. Boger, K. Gordon, T. Dieterle, D. Jager, S. Bauer, Specific inhibition of fibroblast activation protein (FAP)-alpha prevents tumor progression in vitro, Adv. Med. Sci., 60 (2015) 264-272.

[21] S. Tanaka, K. Suzuki, M. Sakaguchi, The prolyl oligopeptidase inhibitor SUAM-14746 attenuates the proliferation of human breast cancer cell lines in vitro, Breast Cancer, (2017) 1-9.

[22] D.M. Evans, Horton, J., Trim, J. E., Fap inhibitors, in: V. Limited (Ed.), United States, 2007.

[23] S.E. Poplawski, J.H. Lai, Y. Li, Z. Jin, Y. Liu, W. Wu, Y. Wu, Y. Zhou, J.L. Sudmeier, D.G. Sanford, W.W. Bachovchin, Identification of selective and potent inhibitors of 
fibroblast activation protein and prolyl oligopeptidase, J. Med. Chem., 56 (2013) 34673477.

[24] K. Jansen, L. Heirbaut, R. Verkerk, J.D. Cheng, J. Joossens, P. Cos, L. Maes, A.M. Lambeir, I. De Meester, K. Augustyns, P. Van der Veken, Extended structure-activity relationship and pharmacokinetic investigation of (4-quinolinoyl)glycyl-2-cyanopyrrolidine inhibitors of fibroblast activation protein (FAP), J. Med. Chem., 57 (2014) 3053-3074.

[25] P.L. Morain, P.; De Nanteuil, G.; Jochemsen, R.; Robin,, D.B. J. L.; Guez, P. A., S 17092: A Prolyl Endopeptidase Inhibitor as a Potential Therapeutic Drug for Memory Impairment. Preclinical and Clinical Studies, CNS Drug Rev., 8 (2002) 31-52.

[26] Drug Profile: S-17092, in: Drug Profile, Springer, Adis Insight, 2016.

[27] J. Lawandi, S. Toumieux, V. Seyer, P. Campbell, S. Thielges, L. Juillerat-Jeanneret, N. Moitessier, Constrained Peptidomimetics Reveal Detailed Geometric Requirements of Covalent Prolyl Oligopeptidase Inhibitors, J. Med. Chem., 52 (2009) 6672-6684

[28] S. De Cesco, Deslandes, S., Therrien, E., Levan, D., Cueto, M., Schmidt, R., , L.-D. Cantin, Mittermaier, A., Juillerat-Jeanneret, L., Moitessier, N., Virtual Screening and Computational Optimization for the Discovery of Covalent Prolyl Oligopeptidase Inhibitors with Activity in Human Cells, J. Med. Chem., 55 (2012) 6306-6315.

[29] G. Mariaule, S. De Cesco, F. Airaghi, J. Kurian, P. Schiavini, S. Rocheleau, I. Huskic, K. Auclair, A. Mittermaier, N. Moitessier, 3-Oxo-hexahydro-1H-isoindole-4-carboxylic Acid as a Drug Chiral Bicyclic Scaffold: Structure-Based Design and Preparation of Conformationally Constrained Covalent and Noncovalent Prolyl Oligopeptidase Inhibitors, J. Med. Chem., 59 (2016) 4221-4234.

[30] P. Schiavini, J. Pottel, N. Moitessier, K. Auclair, Metabolic Instability of Cyanothiazolidine-Based Prolyl Oligopeptidase Inhibitors: a Structural Assignment Challenge and Potential Medicinal Chemistry Implications, ChemMedChem, 10 (2015) 1174-1183.

[31] E. Therrien, P. Englebienne, A.G. Arrowsmith, R. Mendoza-Sanchez, C.R. Corbeil, N. Weill, V. Campagna-Slater, N. Moitessier, Integrating medicinal chemistry, organic/combinatorial chemistry, and computational chemistry for the discovery of selective estrogen receptor modulators with Forecaster, a novel platform for drug discovery, J. Chem. Inf. Model., 52 (2012) 210-224.

[32] C.R. Corbeil, P. Englebienne, N. Moitessier, Docking Ligands into Flexible and Solvated Macromolecules. 1. Development and Validation of FITTED 1.0, J. Chem. Inf. Model., 47 (2007) 435-449.

[33] N. Moitessier, J. Pottel, E. Therrien, P. Englebienne, Z. Liu, A. Tomberg, C.R. Corbeil, Medicinal Chemistry Projects Requiring Imaginative Structure-Based Drug Design Methods, Acc. Chem. Res., 49 (2016) 1646-1657.

[34] S. De Cesco, J. Kurian, C. Dufresne, A.K. Mittermaier, N. Moitessier, Covalent inhibitors design and discovery, Eur. J. Med. Chem., 138 (2017) 96-114.

[35] J.M. Di Trani, S. De Cesco, R. O'Leary, J. Plescia, C.J. do Nascimento, N. Moitessier, A.K. Mittermaier, Rapid measurement of inhibitor binding kinetics by isothermal titration calorimetry, Nat. Commun., 9 (2018) 893.

[36] J.M. Di Trani, N. Moitessier, A.K. Mittermaier, Measuring Rapid Time-Scale Reaction Kinetics Using Isothermal Titration Calorimetry, Anal. Chem., 89 (2017) 7022-7030. 
[37] J.M. Di Trani, N. Moitessier, A.K. Mittermaier, Complete Kinetic Characterization of Enzyme Inhibition in a Single Isothermal Titration Calorimetric Experiment, Anal. Chem., 90 (2018) 8430-8435.

[38] F. Ban, K. Dalal, H. Li, E. LeBlanc, P.S. Rennie, A. Cherkasov, Best Practices of Computer-Aided Drug Discovery: Lessons Learned from the Development of a Preclinical Candidate for Prostate Cancer with a New Mechanism of Action, J. Chem. Inf. Model., 57 (2017) 1018-1028.

[39] C.R. Corbeil, P. Englebienne, N. Moitessier, Docking ligands into flexible and solvated macromolecules. 1. Development and validation of FITTED 1.0, J. Chem. Inf. Model., 47 (2007) 435-449

[40] T. Nakajima, Y. Ono, A. Kato, J.-i. Maeda, T. Ohe, Y-29794 - a non-peptide prolyl endopeptidase inhibitor that can penetrate into the brain, Neurosci. Lett., 141 (1992) 156160.

[41] A. Kato, A. Fukunari, Y. Sakai, T. Nakajima, Prevention of amyloid-like deposition by a selective prolyl endopeptidase inhibitor, Y-29794, in senescence-accelerated mouse, Journal of Pharmacology and Experimental Therapeutics, 283 (1997) 328-335

[42] S. Kaushik, R. Sowdhamini, Structural Analysis of Prolyl Oligopeptidases Using Molecular Docking and Dynamics: Insights into Conformational Changes and Ligand Binding, PLoS ONE, 6 (2011) e26251.

[43] J. Plescia, S. De Cesco, M. Burai Patrascu, J. Kurian, J.M. Di Trani, C. Dufresne, A. Wahba, N. Janmamode, A.K. Mittermaier, N. Moitessier, Integrated Synthetic, Biophysical and Computational Investigations of Covalent Inhibitors of Prolyl Oligopeptidase and Fibroblast Activation Protein a, J. Med. Chem., (2019).

[44] D.F. Veber, S.R. Johnson, H.-Y. Cheng, B.R. Smith, K.W. Ward, K.D. Kopple, Molecular Properties That Influence the Oral Bioavailability of Drug Candidates, J. Med. Chem., 45 (2002) 2615-2623.

[45] J. Plescia, S. De Cesco, M. Burai Patrascu, J. Kurian, J. Di Trani, C. Dufresne, N. Janmamode, A.K. Mittermaier, N. Moitessier, Predicting covalent druggability Application to serine proteases, submitted, (2018).

[46] A. Veera Reddy, Ravindranath, B., Acetylation Under Ultrasonic Conditions: Convenient Preparation of N-Acetylamino Acids, Synth. Comm., 22 (1992) 257-264.

[47] T.A. Kelly, V.U. Fuchs, C.W. Perry, R.J. Snow, The efficient synthesis and simple resolution of a prolineboronate ester suitable for enzyme-inhibition studies, Tetrahedron, 49 (1993) 1009-1016.

[48] H. Fukushima, A. Hiratate, M. Takahashi, M. Saito, E. Munetomo, K. Kitano, H. Saito, Y. Takaoka, K. Yamamoto, Synthesis and structure-activity relationships of potent 3- or 4-substituted-2-cyanopyrrolidine dipeptidyl peptidase IV inhibitors, Bioorg. Med. Chem., 12 (2004) 6053-6061.

[49] C. Lebarbier, F. Carreaux, B. Carboni, J.L. Boucher, Synthesis of boronic acid analogs of L-arginine as alternate substrates or inhibitors of nitric oxide synthase, Bioorg. Med. Chem. Lett., 8 (1998) 2573-2576.

[50] S.J. Coutts, T.A. Kelly, R.J. Snow, C.A. Kennedy, R.W. Barton, J. Adams, D.A. Krolikowski, D.M. Freeman, S.J. Campbell, J.F. Ksiazek, W.W. Bachovchin, Structure-Activity Relationships of Boronic Acid Inhibitors of Dipeptidyl Peptidase IV. 1. Variation of the P2 Position of Xaa-boroPro Dipeptides, J. Med. Chem., 39 (1996) 20872094. 



\section{Table of Content Graphics}

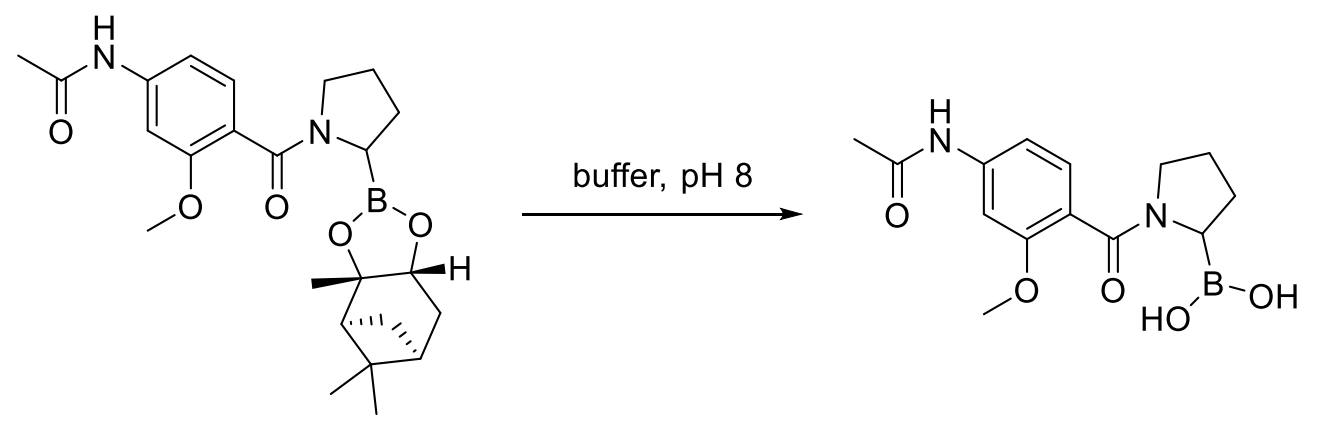

$K_{i}=6 \mathrm{nM}, \mathrm{t}_{1 / 2}<20 \operatorname{mins}$ 